Article

\title{
A Climate Change Adaptation Planning Process for Low-Lying, Communities Vulnerable to Sea Level Rise
}

\author{
Sara Barron ${ }^{1}$, Glenis Canete ${ }^{1}$, Jeff Carmichael ${ }^{2}$, David Flanders ${ }^{1, *}$, Ellen Pond ${ }^{3}$, \\ Stephen Sheppard ${ }^{1}$ and Kristi Tatebe ${ }^{1}$
}

1 Collaborative for Advanced Landscape Planning, University of British Columbia, 2321-2260 West Mall, Vancouver, BC V6T 1Z4, Canada;

E-Mails: sara.fryer.barron@gmail.com (S.B.); gcanete@interchange.ubc.ca (G.C.); stephen.sheppard@ubc.ca (S.S.); Kristine.tatebe@ubc.ca (K.T.)

2 Metro Vancouver, Burnaby, BC V5H 2C8, Canada; E-Mail: jeff.carmichael@metrovancouver.org

3 CALP Affiliate, Pembina Institute, \#610-55 Water St., Vancouver, BC V6B 1A1, Canada;

E-Mail: ellenp@pembina.org

* Author to whom correspondence should be addressed; E-Mail: david.flanders@ubc.ca;

Tel.: +1-604-822-4148; Fax: +1-604-822-9106.

Received: 5 June 2012; in revised form: 26 July 2012 / Accepted: 21 August 2012 /

Published: 11 September 2012

\begin{abstract}
While the province of British Columbia (BC), Canada, provides guidelines for flood risk management, it is local governments' responsibility to delineate their own flood vulnerability, assess their risk, and integrate these with planning policies to implement adaptive action. However, barriers such as the lack of locally specific data and public perceptions about adaptation options mean that local governments must address the need for adaptation planning within a context of scientific uncertainty, while building public support for difficult choices on flood-related climate policy and action. This research demonstrates a process to model, visualize and evaluate potential flood impacts and adaptation options for the community of Delta, in Metro Vancouver, across economic, social and environmental perspectives. Visualizations in $2 \mathrm{D}$ and $3 \mathrm{D}$, based on hydrological modeling of breach events for existing dike infrastructure, future sea level rise and storm surges, are generated collaboratively, together with future adaptation scenarios assessed against quantitative and qualitative indicators. This 'visioning package' is being used with staff and a citizens' Working Group to assess the performance, policy implications and social acceptability of the adaptation strategies. Recommendations based on the experience
\end{abstract}


of the initiative are provided that can facilitate sustainable future adaptation actions and decision-making in Delta and other jurisdictions.

Keywords: adaptation; climate change; vulnerability; flooding; inundation; planning process; participatory planning; resilience; sea level rise; visualization; integrated assessment

\section{Introduction}

While the province of British Columbia (BC), Canada, provides guidelines for flood risk management, it is local governments' responsibility to delineate their own flood vulnerability, assess their risk, and integrate these factors with planning policies to implement adaptive action. However, barriers such as the lack of locally specific data and public perceptions about adaptation options mean that local governments must address the need for adaptation planning within a context of scientific uncertainty, while building public support for flood-related climate policy and action. In the context of climate change, adaptation can be a response of ecological, social, or economic systems to a changing biophysical climate [1]. Review of international urban adaptation programs suggests that a shift towards stakeholder engagement, the improvement of planning tools and governance processes and structures is needed, rather than focusing on technical solutions and physical measures alone [2,3]. The research reported here brings together various physical and land-use adaptive design options within a holistic, multi-stakeholder planning process. It involves a participatory planning process based on science, best practices in the field of community engagement, and visualization, modeling and integrated assessment to provide decision-support for the Corporation of Delta, British Columbia as it engages in coastal adaptation planning.

This section describes the local context for adaptation research and planning in Delta, briefly reviews other adaptation frameworks applicable to municipal adaptation, and lays out the rationale for the approach taken in this study. Section 2 explains the methods used to implement the initial adaptation planning process over a three year period (2010-2013), including the evaluation framework and scenarios for Delta. Section 3 describes the four visualized scenarios which were the results of the adaptation planning process. In Section 4 the paper concludes with a series of recommendations that can overcome limitations and barriers to the facilitation of sustainable adaptation actions and decision-making in Delta and other municipal/regional district jurisdictions.

\subsection{The Context of Delta: A Low-Lying Vulnerable Community}

The Corporation of Delta is a low-lying municipality at the mouth of the Fraser River in British Columbia, Canada (Figure 1). Home to 100,000 citizens, a large portion of the community is at considerable risk from climate change induced sea-level rise and storm surges. Uncertainty in climate science and lack of effective engagement tools are among the reasons why it has been difficult for local governments to build public support for flood-related policy and action. Previous work using climate change response options and 3D landscape visualizations in a visioning process in the area has 
shown that flood scenario visualizations are effective in developing community awareness and support for adaptation needs [4-7]. Enabled by the Regional Adaptation Collaborative (RAC) program of the Canadian government, the Delta-RAC Sea Level Rise Adaptation Visioning Study (Delta-RAC) built on this previous study to generate a range of adaptation scenarios in more depth to inform future climate change planning and move toward implementation in Delta.

Figure 1. Ladner and Boundary Bay, locales in the Corporation of Delta, within the coastal Metropolitan Vancouver area [8].

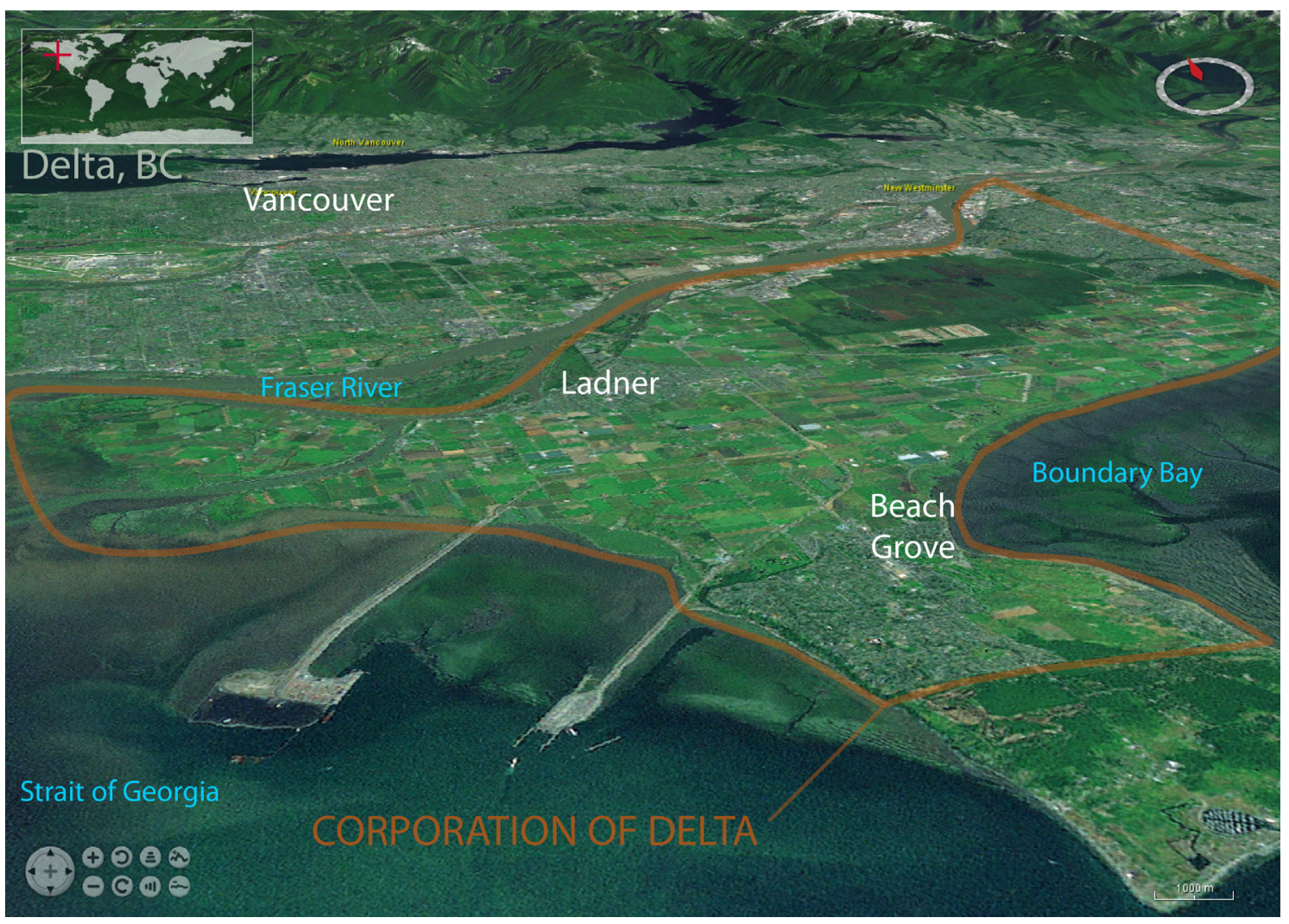

Intended outcomes of the Delta-RAC visioning study were to help further raise public and government awareness, and increase knowledge about climate change, sea level rise, and adaptation options. By working closely with local and provincial government stakeholders, this in turn builds capacity for climate change adaptation, supporting and enabling longer-term decision-making at the local level.

\subsection{Factors Affecting Adaptation Planning in Delta}

A number of important contextual factors exist that are likely to influence the success of adaptation planning in Delta. Current public attitudes and awareness: research has shown in Delta and many Canadian communities that there are high levels of concern about climate change, but very limited awareness of effective adaptation and mitigation solutions, and often resistance to some of these solutions based on economic or quality of life concerns, e.g., opposition to raising seawalls where views and possibly property values would be affected [5]. Other factors that have been observed by the research team during 6 years of research in the community include: 
- Delta has experience significant flooding from both the adjacent Fraser River (most recently in 1948), as well as smaller isolating marine flooding in some communities (most recently in 2006), which has brought the subject of flooding into the public dialogue, e.g., an existing desire for exploring alternative adaptation responses to raising seawalls. This was the aim of the scenarios developed in this study.

- Access to critical scientific, engineering and costing data on the feasibility of possible adaptation measures and scenarios: Delta has commissioned various flood modeling studies to support technical analysis of risks and options, and these studies were integrated into the scenariobuilding and evaluation framework described in Section 2.

- Ownership of coastal properties: key lengths of shoreline in Delta are owned by private homeowners with their own seawalls, as opposed to extensive public dikes in other areas. These private seawalls are outside of the public jurisdiction, making it difficult to generate solutions applicable across the entire community. In part to address this disparity, this study chose two different case study areas, one with a private seawall, the other with a public seawall.

- Key adaptation planning horizons (long-term) and local election cycles (short-term): difficult to align suitable windows, timelines, and strategic incentives for key efforts and decisions to be taken. Although challenging to overcome, this study involved local community, government and staff stakeholders in order to enhance the inertia of the project beyond these cycles.

\subsection{Existing Adaptation Planning Approaches}

A focused review of adaptation planning approaches has observed that many successful approaches draw from local knowledge and expertise through stakeholder engagement, place-appropriate investigation, and can be readily incorporated within existing planning policy $[9,10]$. A community's adaptive capacity is a function of its local context. Adaptive capacity refers to a community's ability to adapt to potential impacts, as well as cope with specific events, based on its social, economic, and institutional resources [11,12]. Increasing a community's adaptive capacity is a way to reduce its vulnerability to climate change related impacts. Communities with a high adaptive capacity could be made more resilient to climate impacts such as coastal inundation if local social and economic resources are focused towards adaptation. The consideration of culture and place-appropriate research can help to increase adaptive capacity in a manner that is sensitive to a community's unique characteristics $[13,14]$. A community's responsive adaptation action-whether to raise buildings to new flood construction levels, raise roads, improve emergency preparedness, or other measures-can reduce the vulnerability of the community.

A number of adaptation planning frameworks exist at varying scales from high level multinational organizations to local-level community planning. This section briefly describes some adaptation frameworks that have been applied to municipal planning.

\subsubsection{United Nations Development Program}

The United Nations Development Program's (UNDP) Adaptation Policy Framework (APF) emerged from an absence of a "clear roadmap" to guide adaptation policy [15]. The APF draws from the foundation provided by the International Panel on Climate Change findings and provides guidance 
on the adaptation process at scales that range from the national to the local level. The framework allows communities to set their own priorities and implementation measures. The framework also emphasizes stakeholder involvement and places equal importance on both strategy and process. The APF is accompanied by "two cross-cutting processes;" the first seeks to keep stakeholders engaged throughout the planning process; the second process ensures that the community's adaptive capacity is increased and continually reviewed [15]. Although the APF allows for the adaptation process to occur at the local level, the scope of the process and the level of adaptive capacity (i.e., the financial and technical capacity of communities) must be appropriate to provide support for scenarios [16]. A key challenge for building scenarios for adaptation planning is the need for scenarios to be sensitive to contextual issues.

\subsubsection{Local Governments for Sustainability (ICLEI Canada)}

The "Changing Climate, Changing Communities: Guide and Workbook for Municipal Climate Adaptation" uses a milestone approach to adaptation planning [17]. The guide and workbook were developed by the Canadian branch of Local Governments for Sustainability (ICLEI Canada). A five-milestone methodology is employed to guide municipal staff through the adaptation process. The ICLEI process is a combination of a variety of approaches including top down (government-led) and bottom up (community-based) as well as hybrid frameworks. The five milestones briefly outline tasks and activities that will assist in the development of adaptation policies: (1) Initiate, (2) Research, (3) Plan, (4) Implement, (5) Monitor/Review. The Initiate (1) milestone begins with the identification of stakeholders and formation of a climate change adaptation team. This team is then expected to draw from existing regional climate knowledge. A key component to this stage is to build political support through the identification of a climate change champion to take a leadership role through the adaptation process. The Research (2) phase involves scoping climate change impacts relevant to the community through risk and vulnerability assessments. The third milestone, Plan builds on the previous two phases, starting with the establishment of an adaptation vision, goals and objectives. Following this, an adaptation action plan may be drafted which can include baseline data, finance and budget, delineation of implementation responsibilities, and the basis of an implementation plan. The adaptation action plan can then be finalized. The Implement milestone (4) requires the approval of the community, council and staff as well as effective resources for implementation. The monitor/review phase (5) functions as an assessment phase to monitor and evaluate whether the community's goals and objectives have been met. Progress through the adaptation process may also be communicated to the public.

The ICLEI approach draws from both the UNDP and IPCC; however, the process has been significantly streamlined for the use of decision-makers and stakeholders. The approach allows for review of each phase and implies that iteration may take place between the phases, but for the most part the stages are structured in a linear manner with the majority of stakeholder and community involvement occurring at the outset and in the implementation stage. Mapping, scenario creation and visualizations are not currently built into the ICLEI framework, but their inclusion could enrich this process. Delta is engaged in the ICLEI adaptation process and is approaching the first milestone. 


\subsubsection{Local Adaptation Planning Examples}

\section{- Community-based workshop in Prince George, British Columbia, Canada}

A research team conducted a workshop over a single day in the community of Prince George located in northern British Columbia, Canada with the purpose of identifying adaptation planning strategies. The workshop addressed the need to identify adaptation planning strategies due to variations in temperature related to climate change that outpace the global mean, which have resulted in warmer winters and its associated impacts on the community [9]. The researchers' approach to the workshop framework was based on their findings that adaptation processes involving community stakeholders often yield results with greater social acceptability, are grounded in local knowledge, and work towards a higher level of public awareness on the need for adaptation. The researchers reported successful results from their work in the community in achieving their intended objectives, which were to raise awareness of climate impacts and to prioritize impacts for adaptation action and implementation [9].

\section{- Adaptation integrated into overarching policies in King County, WA, USA}

King County is located in northwestern Washington State in the United States. In March 2006, the regional government ordered the County to provide global warming preparedness plans. In response to this legislation the County produced the King County Climate Plan in 2007. The intention of the King County Climate Plan is to integrate adaptation into existing policy. The Climate Plan was a result of a comprehensive suite of adaptation initiatives that began in 2005 with an adaptation conference hosted by King County that had over 650 participants in attendance from various stakeholder groups including: state and regional government, private and non-profit businesses, tribes, farmers and interested community members [18]. The conference served to raise awareness on climate change impacts and adaptation and identify priority areas for policy formulation [19]. The focus of the Climate Plan is to outline goals and objectives for climate adaptation and mitigation on county planning aspects such as: land use, growth management, transportation, water and environmental management and clean energy [18]. Overarching county policies, such as the King County Comprehensive Plan, Shoreline Master Program and the King County Flood Hazard Management Plan, have all been revised to accommodate adaptation planning. For example, amendments to accommodate for climate change related impacts have been made to The King County Flood Hazard Management Plan to include a Flood Buyout and Home Elevation program. Buyouts are extended to homeowners in selected neighborhoods who are at the highest risk of inundation. The land is then converted to permanent open space [20]. The home elevation portion of the program assists homeowners with property located in floodplains or floodways in flood proofing and raising the finished floor level of homes above the 100-year flood elevation. Decision-makers and stakeholders in King County have integrated adaptation frameworks into actual adaptation policies and implementation programs. Efforts stemming from the King County Climate Plan are reviewed annually as part of the plan's implementation and monitoring [18].

\section{- Community-based adaptation framework The Columbia Basin Trust, BC, Canada}

The Columbia Basin Trust (CBT) is a regional organization that supports community development within the Canadian portion of the Columbia River Basin in British Columbia. The CBT utilizes a 
two-phase approach to adaptation planning to generate a six-step planning framework. The CBT's approach occurs from the bottom up where the lessons acquired from community engagement processes in Kimberley and the District of Elkford were combined with climate science to inform a six-step adaptation approach, the Adaptation Resource Kit Six-Step Planning Process [21]. The process's six steps include the following: 1. Get Started 2. Learn About Climate Change 3. Identify Priorities in Your Community 4. Assess Vulnerability and Risk 5. Develop Adaptation Strategies and Actions 6. Implement and Monitor Plans [21]. The preliminary community engagement phase permitted the integration of local knowledge expertise and resources with the adaptation planning process. Working groups consisting of municipal council members, city staff, local Steering Committee members and stakeholders identified and prioritized vulnerabilities to climate related impacts [11]. The second phase takes the lessons acquired from the previous phase and applies them to a six-step planning process where the stakeholders are continually consulted from the outset to identify priorities, assessing vulnerability and risk, adaptation strategy and action development and through to implementation and monitoring.

As part of CBT's community-based adaptation strategy in Kimberley, the University of British Columbia's Collaborative for Advanced Landscape Planning conducted a study that developed 3D landscape visualization tools in collaboration with a project Steering Committee. The visualization tools served to communicate the impacts of climate change on the community through adaptation and mitigation scenarios. Two general scenarios were devised: the first "Kimberley Adapts" illustrated a future Kimberley that focused on adaptation measures that assumed the existing level greenhouse gas emissions in the community would persist without mitigation, and the second scenario "Low Carbon Kimberley" envisioned a future where the adaptation and mitigation strategies worked in tandem [11,22]. The scenarios uncovered vulnerabilities in energy resources, food security, transportation and economic drivers such as tourism in the community.

\section{- Sea level rise adaptation planning in Halifax, NS, Canada}

Several studies on climate adaptation have been conducted in the area of Halifax, Nova Scotia, Canada. The School of Planning, Dalhousie University conducted an Environmental Planning Studio exercise to assess the vulnerability of a harbor area $45 \mathrm{~km}$ outside of the city centre, and make recommendations for future land use and sea level rise adaptation policies [23]. It reviewed and selected locally relevant estimates of sea level rise, provided a detailed environmental site inventory and analysis, and conducted an assessment of vulnerability drawn from the IPCC's definition based on the relationship between sensitivity and exposure. Adaptation strategies included "Retreat", "Defend", and "Wait and See". In addition to this rural study, Natural Resources Canada's Geological Survey of Canada (NRCan) conducted a scenario-based, quantitative and spatial study of potential impacts in the urban Halifax Harbor area [24]. The NRCan study was presented to the Halifax Regional Council in 2010.

Although no single study reviewed represents a full suite of techniques for engagement, scientific modeling, scenario-building, analysis, and integration with local government planning via a holistic process, they none-the-less represent vital elements for successful local adaptation planning in populated areas. 


\subsection{An Adaptation Process for Delta}

Based on this review of applied adaptation frameworks, local case studies and existing contextual factors in Delta, several key themes emerge for successful adaptation planning, such as:

- Keeping stakeholders engaged via a bottom-up planning process by conducting workshops with all community stakeholders; providing education and awareness-building; priority-setting; a vulnerability assessment; ensuring that the community's adaptive capacity is increased and continually reviewed; considering social acceptability of proposed adaptation strategies by, for example, using 3D visualization tools (from United Nations Development Program; Prince George, BC; Columbia Basin Trust)

- Designing a set of deliverables to inform the milestones of the ICLEI Canada Guide for Municipal Adaptation. In the case of Delta, the first three milestones of Initiate, Research and Plan were focused on (from ICLEI Canada)

- Integrating adaptation into local policy, particular policies for highly vulnerable areas (from King County, $W A$ )

- Integrating the IPCC's conceptual definition of vulnerability as a function of "sensitivity" and "exposure"; packaging adaptation strategies into coherent scenarios for communicating to stakeholders and regional authorities (from Halifax, NS)

This paper attempts to establish a dual adaptation planning strategy at the municipal-level comprised of:

i) a social learning and capacity-building program, sustained over a period of several years, for the Delta community and municipal staff to become familiar with the realities of sea level rise and key concepts of climate change adaptation. This would embrace existing and new public engagement/educational opportunities, including methods such as those employed in this study and a media strategy to take advantage of media interest and responsible information dissemination. The goal is for an inclusive, structured, and informed public dialogue with shared learning on all sides, conducted well before major decisions are taken. Building public support for policy change and implementation of adaptation measures will be important in attracting funding and reducing uncertainties and costs.

ii) a planning process to develop required information to frame community discussions and for decision-making, including input from stakeholders and partners, and commissioning or sharing in new scientific and technical studies. The goals of this process would be to:

- $\quad$ Provide a strong basis for lobbying higher government and other potential funding sources;

- Identify and exploit win/win opportunities in meeting multiple objectives such as adopted carbon emission reduction targets and reducing dependency on fossil fuels, providing more jobs in Delta and developing the local tax base, safeguarding community assets such as wildlife and agricultural production, improved transit, etc.;

- Form strategic alliances with other communities and agencies on issues such as local food security, funding technical studies, continuity in infrastructure approach across municipal boundaries, etc. 
To meet these dual needs, it was decided to adopt and further adapt the adaptation planning process previously used for the Delta communities, known as the Local Climate Change Visioning Process, developed by the Collaborative for Advanced Landscape Planning at the University of British Columbia (UBC CALP) [4,6,22]. This process employs a holistic framework through an iterative adaptation planning strategy that integrates explicit spatial mapping based on best available modeling and GIS analysis, alternative future flood scenarios, and 3D landscape visualization imagery. Building on the earlier visioning work in Delta [4], Vancouver's North Shore [25], and Kimberley as described above [11,26], this approach responds to the need for tangible, clear, compelling and meaningful 3D imagery based in science, in combination with quantifiable mapping and metrics [27] with which to assess the pros and cons of alternative adaptation scenarios. The intent is to disclose as credibly as possible the consequences of climate change impacts and adaptation measures, even if potentially harsh or alarming, while also providing citizens and decision-makers with practical options and creative solutions that a community could explore further through a positive collaboration process. This process is adaptable for any local government working on climate change visioning and has been documented as a Guidance Manual for communities [22]. It was conducted in Delta outside of any official planning process, though with full support of Delta staff, in order to use the research project as a testing ground for further more formal planning and engagement processes.

\section{Methods}

\subsection{Overall Process}

The Delta-RAC Local Climate Change Visioning process took place in three phases (see Figure 2):

1: Participatory Scenario Building and Indicator Definition

2: Data Integration, Modeling, and Visioning Package Development

3: Policy Implications, Capacity Building and Dissemination

Figure 2. The planning process: iterative, flexible, participatory, and grounded in science and modeling [28].

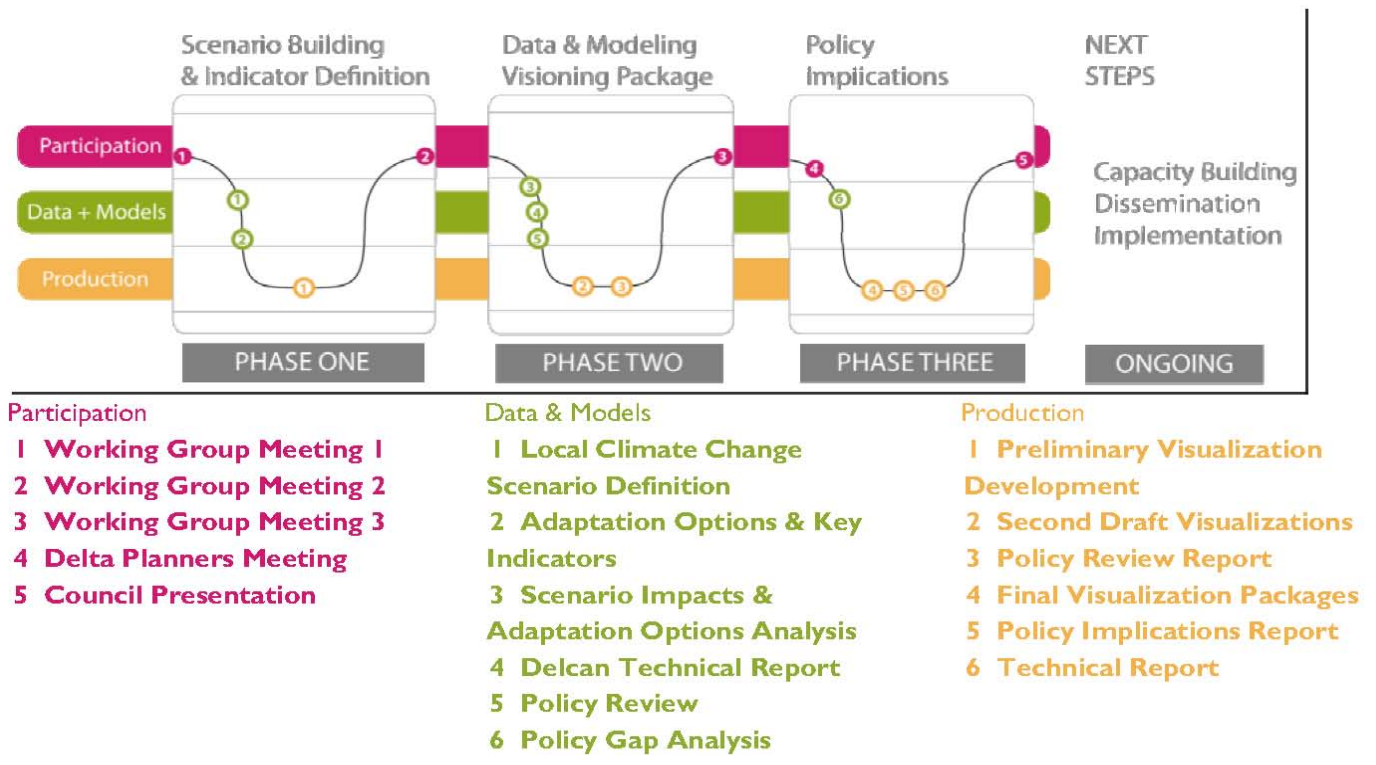


Phase one, Participatory Scenario Building and Indicator Definition, took place in the first year of the project. Key activities included creating a work plan for the entire project, establishing a time scale and geographic scope for the analysis, determining critical baseline (current) data and future climatic data projections, creating a list of relevant potential economic, environmental and social indicators, and creating draft scenarios for analysis. Geographic scope varied across indicators: for example, the local impact of dike upgrades was shown visually for two particular neighborhoods, but impacts on agricultural land were considered across the entire corporation. Plans were established for participatory collaboration with both corporation technical staff and with engaged local community members. The latter were included through the creation of a community Working Group of about 12 people, which interacted with the full team at various times over the course of the project.

The second phase, Data Integration, Modeling, and Visioning Package Development, took place in the second and third years of the project. In this phase, the team used the draft scenario frameworks generated in phase one, and gathered additional data to create preliminary visualizations. These visualizations were then tested through multiple review workshops with Delta staff, the working group, and invited experts. The visuals were revised and refined based on the feedback received. At the same time, the indicators were refined and measured. The main outcome was a final set of 2D maps and 3D visualizations for the scenario frameworks, and indicators with which to compare them. These final packages were presented to Delta staff, the working group, and invited experts for final feedback and refinement.

The final phase, Policy Implications, Capacity Building and Dissemination, used the Visioning Packages and on-going policy review to draft a set of policy implications for each scenario. These were brought to Delta Staff and then finalized in a Policy Report [29]. A technical report was also prepared to share key project lessons related to data gathering and modeling [30]. Project outcomes were presented to Delta Council, and will be disseminated through a dedicated website [31].

\subsection{Evaluation Framework}

The Local Climate Change Visioning process for Delta-RAC used a conceptual Evaluation Framework throughout the project, primarily in phase two, to help identify, model, visualize, and evaluate adaptation options for the Corporation of Delta. The framework uses three linked-methodologies, as the basis for generating recommendations for further adaptation planning:

1) Model climate scenario impacts (focused on sea level rise)

Climate scenario impacts are defined by combining local climate science data, linked to global climate science and emissions data, with local knowledge to project the best available scenario(s) of future climate impacts for a particular community. Some localized assessments of climate impacts have been generated for Delta. In January, 2011, Delta and CALP commissioned a Sea Level Rise Breach Analysis, reported in a Technical Memorandum. This was to simulate dike breach events for the areas of Ladner and Boundary Bay Regional Park (adjacent to Beach Grove) that demonstrated the effect of up to $1.2 \mathrm{~m}$ of sea level rise on inundation depth and extent [32]. In addition, the BC Ministry of Environment commissioned two reports that describe the coastal hazards, climate science, potential 
climate impacts, management and design criteria for land use and sea dike construction in low-lying coastal areas. It includes a summary of relevant coastal hazards such as localized projections of impacts for coastal areas across $\mathrm{BC}$, storm surge modeling, as well as design and management guidelines for the Fraser River Delta [33,34].

After reviewing several sea level rise projections that account for the uncertainty around a range of climate scenarios, though not their general trajectory indicating increasing sea levels, the team chose to move forward with the projection of $1.2 \mathrm{~m}$ of sea level rise. This is a median projection between higher forecasts of around $2 \mathrm{~m}$ and lower forecasts of around $0.5 \mathrm{~m}$ by 2100 . The $1.2 \mathrm{~m}$ forecast corresponds to the British Columbia Ministry of Environment's recommended projection of sea level rise and other coastal hazards for planning and design in BC (see Table 1).

Table 1. Current and future contributions of coastal hazards in Delta, British Columbia (BC) [33].

\begin{tabular}{|c|c|c|}
\hline & 2010 Guideline & 2100 Guideline \\
\hline $\begin{array}{l}\text { Summary of Coastal Impacts on } \\
\text { Sea Level for Fraser River Area }\end{array}$ & (CGD, $\mathrm{m}$ above mean sea level) & (CGD, $\mathrm{m}$ above mean sea level) \\
\hline $\begin{array}{l}\text { Reference Tide Level (Higher } \\
\text { high water large tide) }\end{array}$ & $1.8 \mathrm{~m}$ & $1.8 \mathrm{~m}$ \\
\hline Sea Level Rise & $\mathbf{0 ~ m}$ & $1.2 \mathrm{~m}$ \\
\hline $\begin{array}{l}\text { Storm Surge (Change in water } \\
\text { level from wind and air pressure) }\end{array}$ & 1.25 m (1/200 yr storm) & $1.3 \mathbf{~ m}(1 / 500 \mathrm{yr}$ storm $)$ \\
\hline Waves & $0.65 \mathrm{~m}$ & $0.65 \mathrm{~m}$ \\
\hline $\begin{array}{l}\text { Wind Set Up (Rise of water } \\
\text { surface due to wind stress on water } \\
\text { surface) and } \\
\text { Wave Runup (Vertical distance } \\
\text { that waves run up the slope of a } \\
\text { shoreline or shore structure) }\end{array}$ & $1.8 \mathrm{~m}$ & $3.1 \mathrm{~m}$ \\
\hline
\end{tabular}

2) Creating and visualizing scenarios

Scenarios represent potential long-term policy alternatives that an area or community could choose to adapt to future flooding risks. Although no particular scenario would likely be implemented in isolation from other options, the scenarios are presented and analyzed separately to aid understanding of the benefits and weaknesses of each particular approach. Scenarios were presented as plausible but distinctly different alternatives with no pre-conceived notions of which might be preferable or likely. It is expected that communities would create more nuanced, blended approaches for public consideration and potential implementation.

Scenarios are combined quantitative and qualitative narratives about possible future conditions. They provide a mechanism to consider comprehensive future states in a coherent and easy-to-grasp manner. By providing a framework within which communities can explore "what if" questions, scenarios can help communities:

- explore a range of options

- understand trade-off choices

- understand long-term consequences 
- make decisions at a smaller case-study scale, as well as understand the larger framing political issues

Scenarios provide a framework to address holistic, future climate change possibilities and current and future response options. The objective is to describe complex and uncertain alternative future pathways as simply as possible in "plausible storylines" or scenario narratives, tied to quantitative modeling where possible.

Scenarios provide a structured way to ask "what if" questions that explore risks, planning options, and possible outcomes while accounting for uncertainty, surprise, human choices, cultural values and complexity. In order to provide a range of possible futures, scenarios are based on modeled quantitative data (such as population projections) or quantitative assumptions, as well as qualitative data including cultural values and norms. They are thus multi-dimensional, and combine diverse elements including socio-economics and the environment.

Scenarios are schematic, aiming not for precision and detail but for essential elements and plotlines that articulate large-scale patterns. Therefore, scenarios do not express probability, but rather are used to book-end a range of possible futures. They often include extreme cases, e.g., from the "Do-Nothing" climate change scenario with very severe impacts, to the "do everything" scenario with both adaptation and extensive mitigation associated with stabilizing the future climate. The "Do Nothing" scenario is included principally to aid understanding of the need to take action of some kind, through seeing the consequences of not taking action. "Do Nothing" is not expected to be a viable option for consideration by the Corporation of Delta. The extremes of alternative scenarios are intentionally distinct from one another so that the long-term community benefits and weaknesses of each approach can be clearly understood.

The scenarios were created by the research team based on literature review and team experience, and were revised through repeated interaction with Corporation of Delta staff and the community Working Group. Each scenario was associated with multiple local trends, drivers, and other underlying assumptions and data on topics such as population growth, energy use, and other socio-economic factors.

3) Evaluating scenarios against key indicators and implications

Indicators help to measure the differences and potential performance across scenarios. An initial, broad set of indicators was first established to represent a wide range of economic, environmental and social issues within the community, and then later narrowed to a key set of indicators supportable by data and resources. The indicators include both quantitative and qualitative issues (see list in Section 3).

Once the four adaptation scenarios were constructed and spatialized using ESRI ArcGIS mapping software, their performance was measured using finalized key indicators, to provide metrics to assess the trade-offs between scenarios. A useful indicator is one that is sensitive to differences across scenarios, therefore highlighting the consequences of committing to one adaptation strategy over another. A suite of indicators covering environmental, social and economic concerns was compiled and applied to the scenarios. The final selection of indicators was based on priorities within the working group, data availability, and relevance for informing local climate adaptation policy.

Indicators used here represented sectors that are vulnerable to climate change impacts if no adaptation action is taken. The final set of indicators address a range of issue areas, including: 
agriculture, habitat, infrastructure, transportation, housing, land use, quality of life, ongoing risk/vulnerability, and certain associated cost indicators.

Review of the final assessment emerging from this process led to revisions to the list of key indicators necessary for understanding scenario implications. For example, the visualizations led to more qualitative understandings of the scenario impacts, such as how the character of the streets might change. The indicators helped the team understand more quantitative implications, such as how much land area would be affected by sea level rise. When combined, the framework components provide a structured approach for understanding and evaluating the adaptation options and developing further recommendations.

The Delta-RAC scenarios were developed through the project process and by using the evaluation framework (described above). Using an iterative process, the project team created and refined scenarios for consideration, and selected criteria that were relevant to Delta communities and for which analysis support was possible.

The next section describes the broad concepts defining the scenarios. Characteristics of the scenarios include the extent to which they maintain (defense), lose (retreat), or expand (offense) the lands under some level of protection within the sea level rise planning area (defined as all lands at or below $5.6 \mathrm{~m}$ above sea level, GCD) [33]. The strategies can also be characterized by the extent to which they use "armoring" engineering solutions to keep water out, or "soft" approaches that allow for some ocean encroachment and opportunities for unique community forms (see Figure 3).

Figure 3. In this framework, the adaptation scenarios can be compared by the extent to which they defend or take offensive action, and armor or use softer approaches against sea level rise [35].

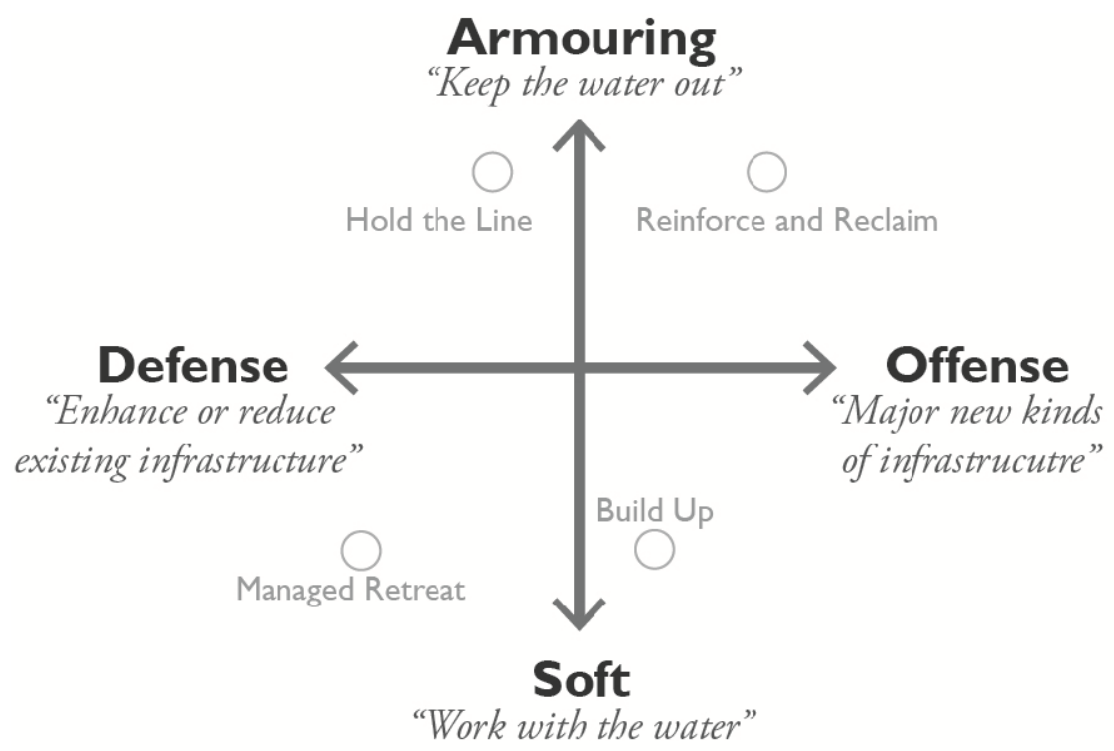

\section{Results}

\subsection{The Four Adaptation Scenarios}

This section describes the broad concepts defining the scenarios. The Scenarios summarized here show hypothetical conditions assumed to be in place by 2100 . The date by which such policy would 
need to be completed has not been included as part of this project. A description of each scenario is provided, followed by a map showing the changing land use incorporated, along with 3D visualizations and indicator measurements.

\subsubsection{Hold the Line}

This armoring scenario maintains, strengthens, and raises most of the existing $55 \mathrm{~km}$ of Delta's dike and seawall infrastructure in order to protect against sea level rise (see Figure 4). By 2100, the dike infrastructure would maintain the current developed area boundary and there would be no net gain or loss of land with the exception of reduced intertidal habitat outside the dikes. Westham Island's sub-standard infrastructure would not be upgraded, and the Island would eventually become an open space/habitat area that is seasonally inundated. This Scenario assumes that the dike/seawall infrastructure is built to a very high standard of 6.9 meters above mean sea level- consistent with the new BC Sea Dike Guidelines (see Table 2) to ensure that the probability of infrastructure failure (breaches and flooding) is extremely low (near zero). This scenario assumes that flood construction levels inside the dikes are not raised, and would likely be developed over many decades.

The BC Ministry of Environment recommended dike crest elevations and flood levels that were used to produce the visualizations (see Table 2). The team chose to model seawalls in Boundary Bay at 6.9 meters above mean sea level, as recommended in the guidelines. The dikes in Ladner are modeled one meter lower at about 5.9 meters, as recommended by experts, because Ladner would not experience the same intensity of waves and storm surges (communication with stakeholder coastal engineer). Generally, the imagery shown for South Delta was received with skepticism on the efficacy and acceptability of this strategy being implemented there. In Ladner, the imagery prompted discussion on the detailed qualities/design that would make this strategy feasible, such as by re-routing traffic from a narrow River Road, or providing public amenities such as a greenway atop the raised dike. Hold the Line is visualized in Ladner and South Delta in Figures 5-8. 
Figure 4. The Hold the Line Scenario upgrades Delta's dike and seawall infrastructure (red line) to protect Delta's existing low-lying areas from sea level rise. The brown areas on the map below are protected from flooding [36].

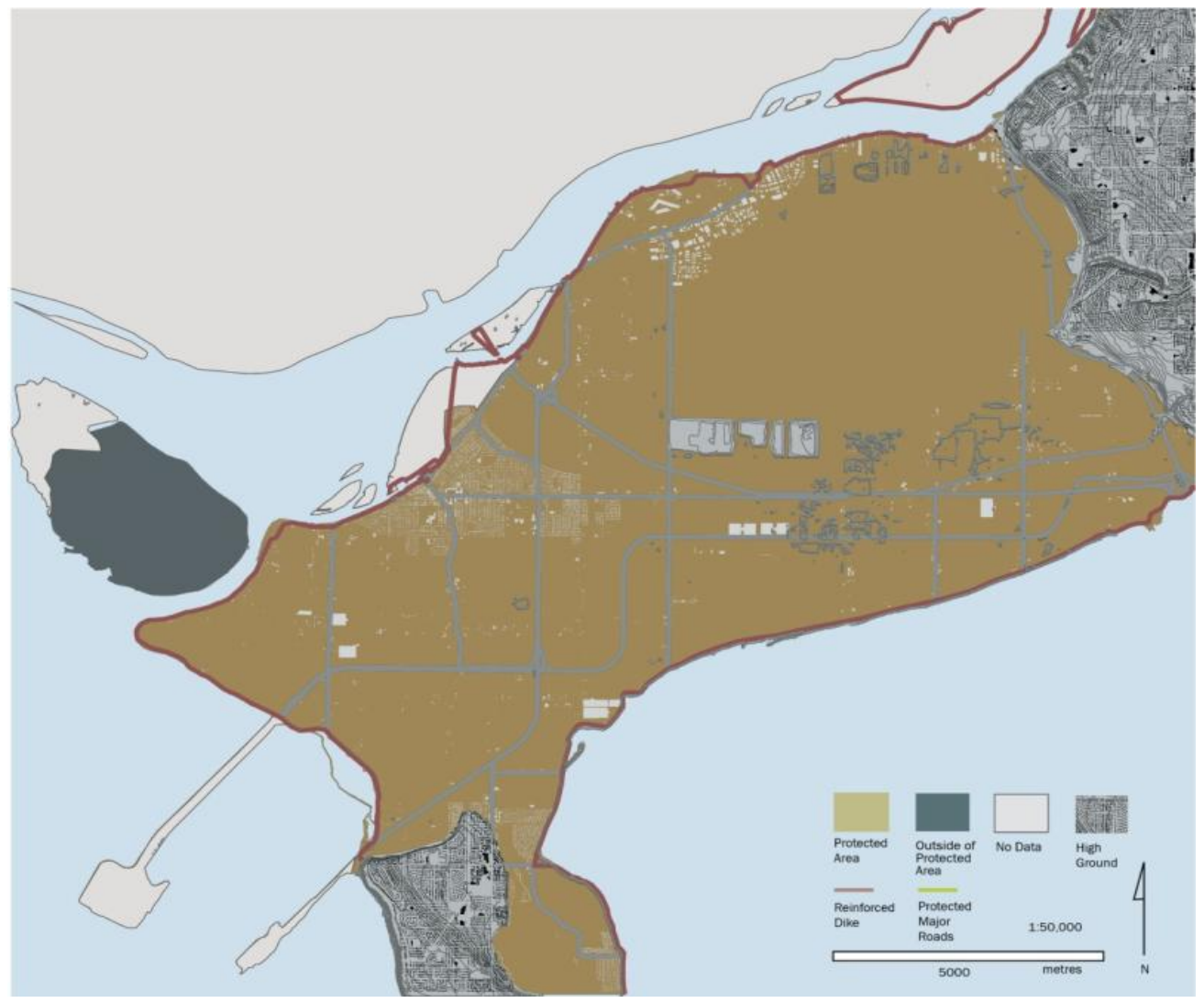

Table 2. BC provincial Sea Dike Guidelines [33].

2010 Guideline

\begin{tabular}{lcc}
\hline Sea Dike Guidelines & (CGD, m above mean sea level) & CGD, m above mean sea level) \\
\hline $\begin{array}{l}\text { Designated Flood Level (Includes } \\
\text { maximum high tide, sea level rise, } \\
\text { storm surge and wind) }\end{array}$ & $\mathbf{3 . 4 5} \mathrm{m}$ & $\mathbf{4 . 8 ~ \mathrm { m }}$ \\
\hline $\begin{array}{l}\text { Dike Crest Elevation (Accounts } \\
\text { for wave run-up, overtopping, wind } \\
\text { and wave setup) }\end{array}$ & $\mathbf{4 . 4} \mathrm{m}$ & $\mathbf{6 . 9} \mathrm{m}$ \\
\hline
\end{tabular}

2100 Guideline 
Figure 5. Current conditions in Ladner, Street View down River Road [37].

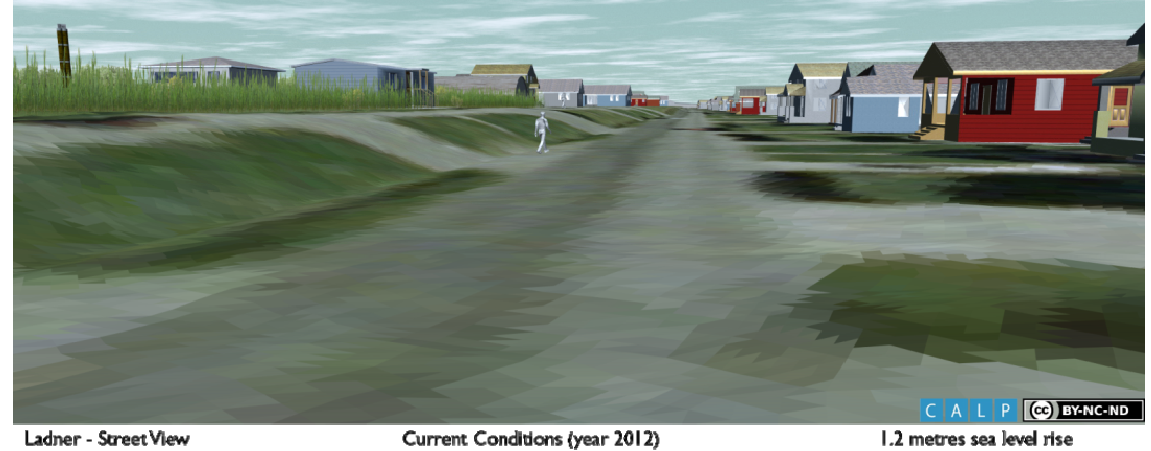

Figure 6. Hold the Line Scenario, Ladner, Street View, dike adaptation with 1:3 Slope [37].

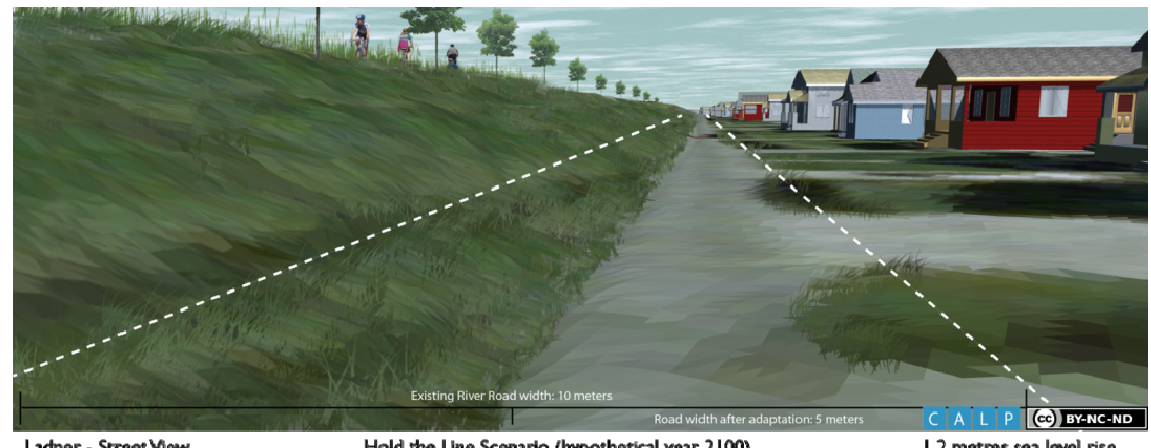

Figure 7. Hold the Line Scenario, Ladner, Street View, Concrete Wall adaptation [37].

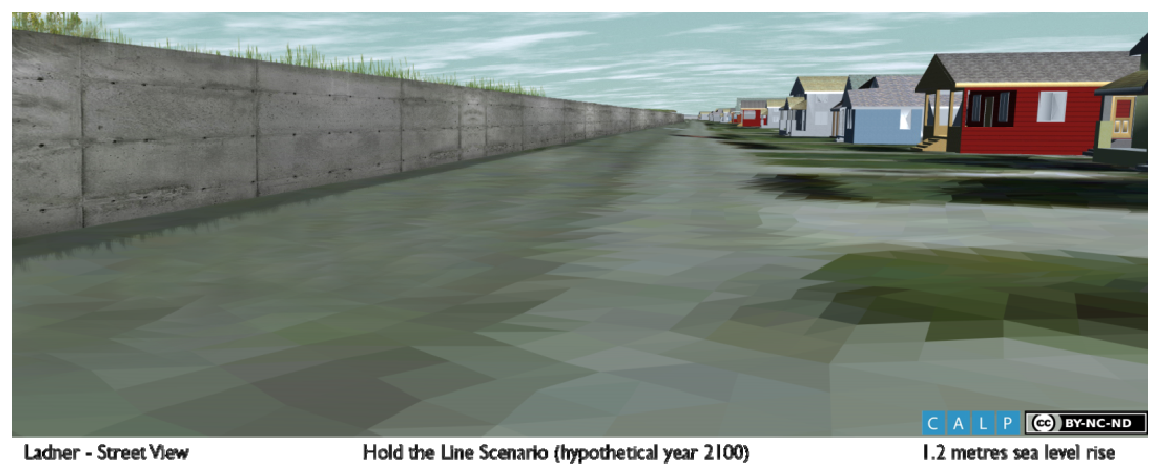

Figure 8. Hold the Line Scenario, Beach Grove, Seawall View. The seawall in Beach Grove is raised to meet the new guidelines [37].

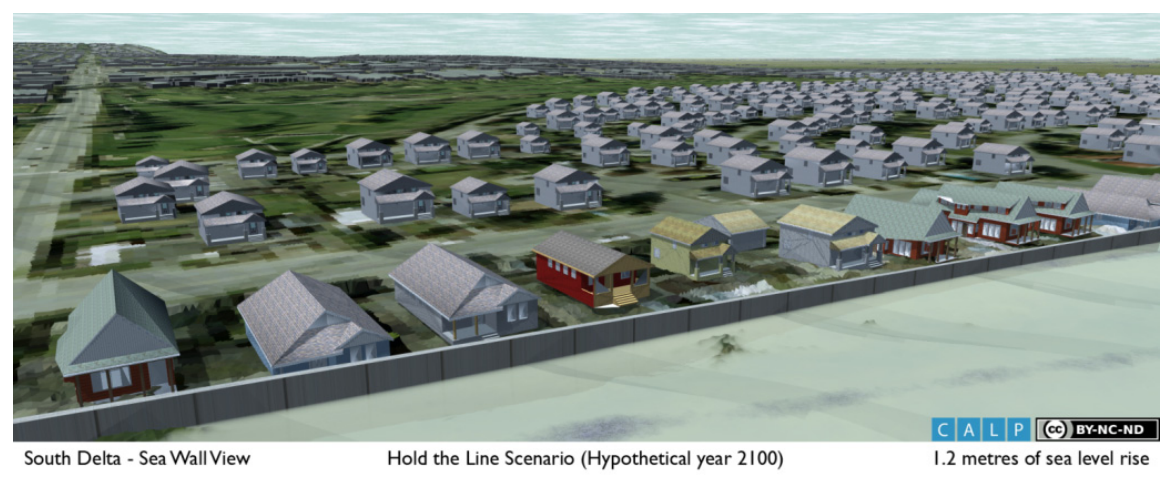




\subsubsection{Reinforce and Reclaim}

This armoring scenario maintains, strengthens, and raises most of the existing $55 \mathrm{~km}$ of Delta's dike and seawall infrastructure in order to protect against sea level rise (see Figure 9). In addition, outer dikes would close off some areas from the river/sea (e.g., Ladner Harbor and Deas Island to protect the Massey Tunnel exit). Ecologically functional barrier islands would be used to reduce the probability or extent of inundation along Boundary Bay. By reducing incoming wave energy, and mitigating incoming tide and storm surge effects off-shore, the barrier islands would allow for slightly lower dikes or seawalls around Boundary Bay as compared to those in Hold the Line. For several members of the working group, Reinforce and Reclaim became a preferred, softer alternative to Hold The Line and is visualized in South Delta in Figure 10.

Figure 9. Map showing the Reinforce and Reclaim Scenario, where barrier islands (white areas in lower right part of map) combine with smaller dike upgrades (red line) to protect Delta's low-lying areas from sea level rise [36].

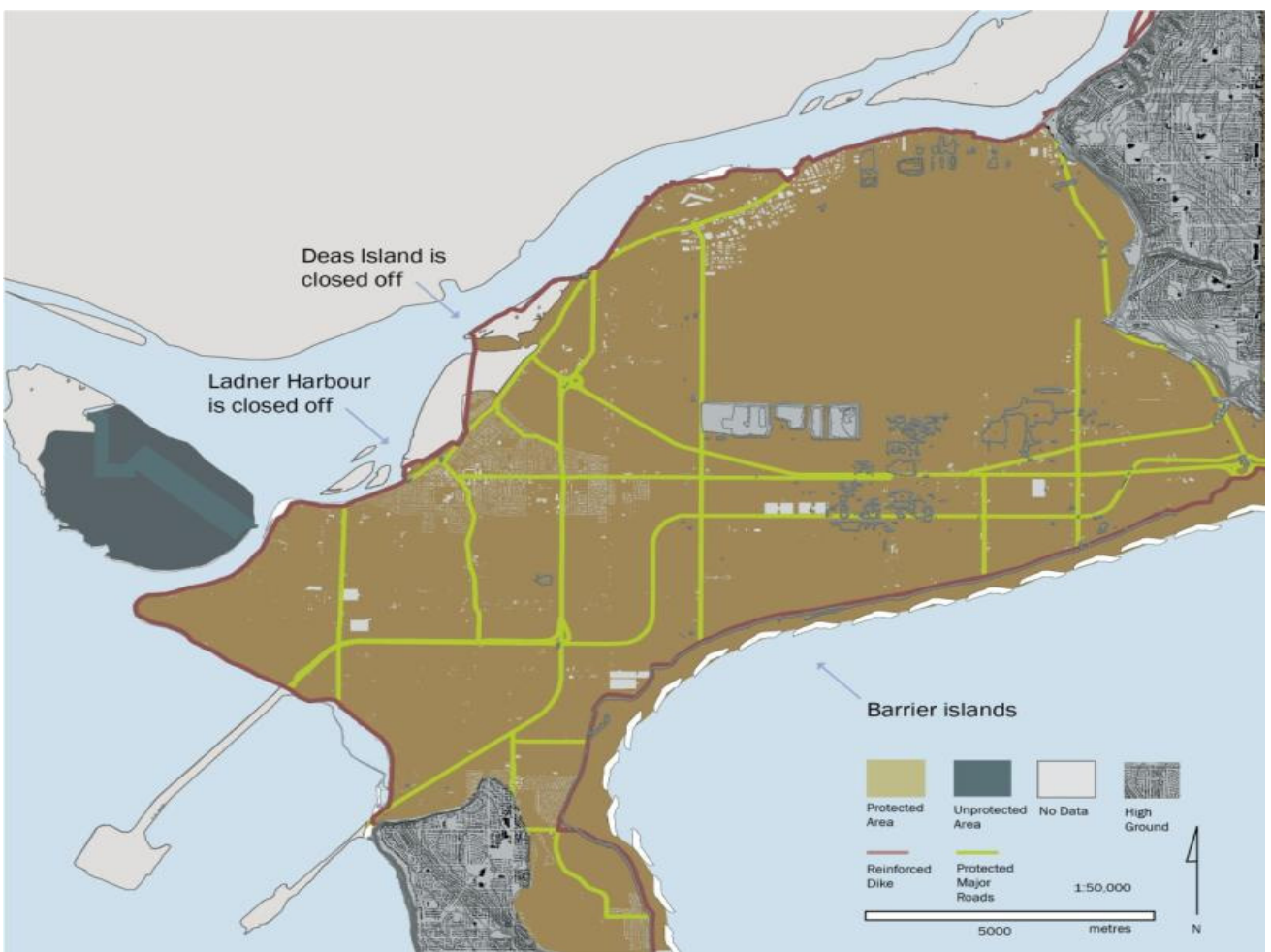

Figure 10. Reinforce and Reclaim Scenario, Beach Grove, Aerial View [37].

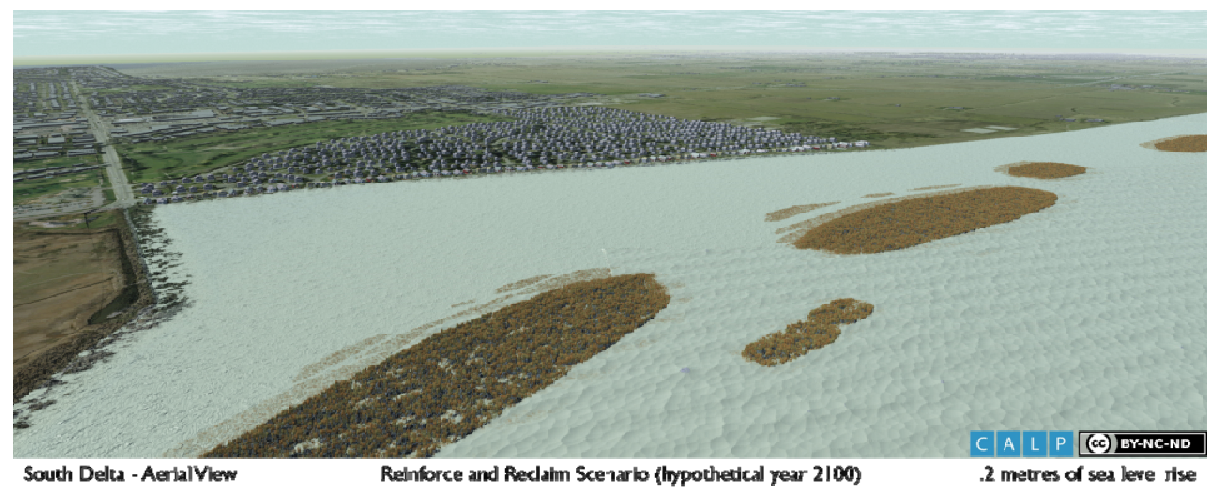




\subsubsection{Managed Retreat}

This "soft" option leaves existing dike and seawall infrastructure as is for many areas, reinforcing and maintaining existing infrastructure only to protect major population concentrations and Delta-wide assets in Ladner (see Figure 11). As a result, over time, sea levels would inundate the remaining unprotected low-lying areas. Development currently located in these unprotected areas would be gradually relocated to higher-ground or Ladner, in a phased and planned retreat over several decades. This Scenario combines the adaptive strategy of improved dike infrastructure with the adaptive strategy of reducing community vulnerability by planned re-location. A controversial strategy, by visualizing the gradual managed retreat of South Delta over time, many stakeholders were able to talk through the sequential planning steps that would be required to achieve it (see Figures 12-15). Managed retreat is visualized in Ladner in Figure 16, showing a protected urban center with inundation occurring in South Delta in the distance.

Figure 11. The Managed Retreat Scenario Map. The Scenario proposes to retreat out of some of Delta's lower density, low-lying areas over several decades [36].

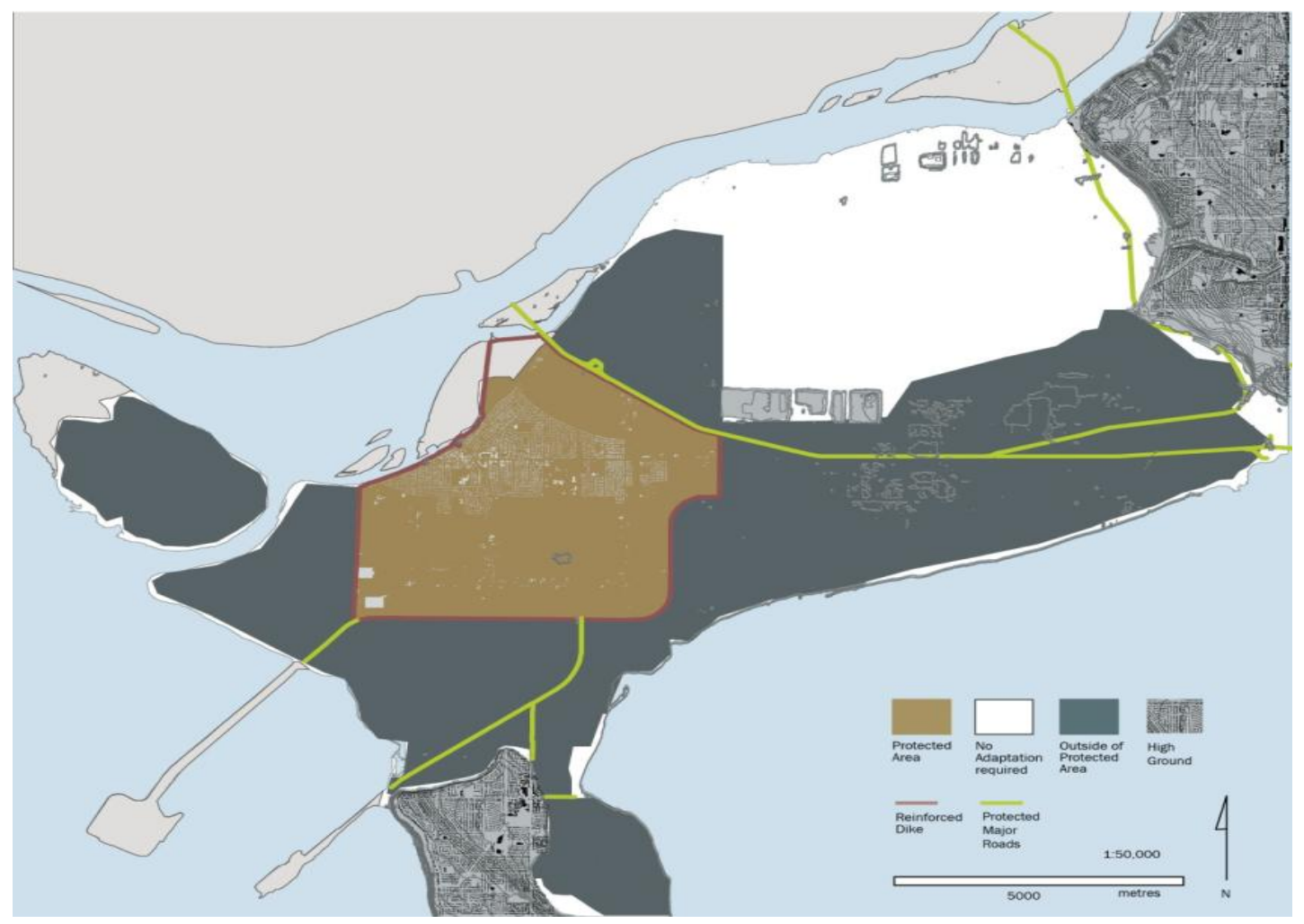


Figure 12. In the first stage of the Managed Retreat Scenario in South Delta, the primary access roads are raised to the current flood construction levels [37].

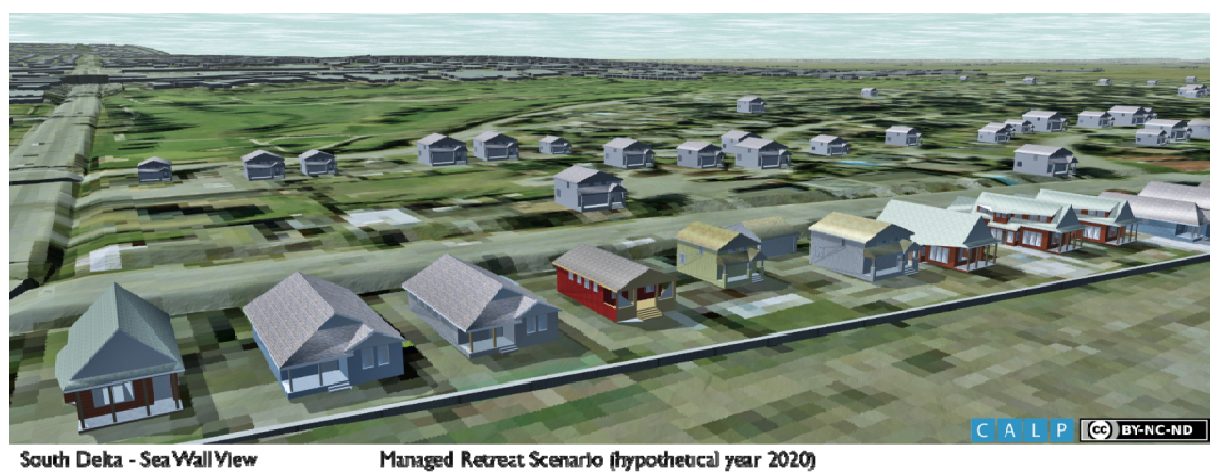

Figure 13. In the second stage of the Managed Retreat Scenario in South Delta, some residents have moved elsewhere, though the community is less vulnerable to temporary inundation [37].

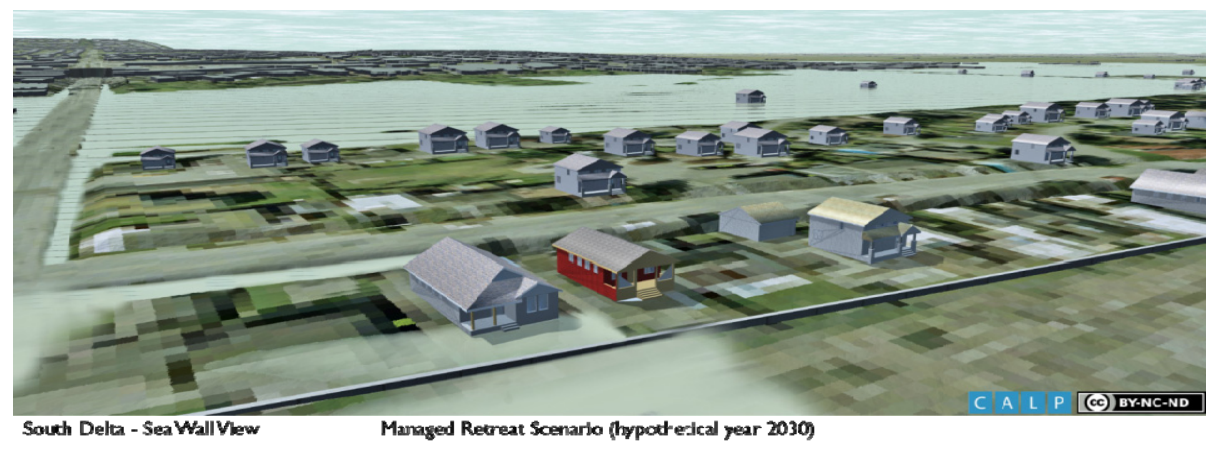

Figure 14. In the third stage of the Managed Retreat Scenario, fewer residents live the floodplain as the coastline re-aligns with rising sea levels and instead choose to live in the higher lands shown in the distance [37].

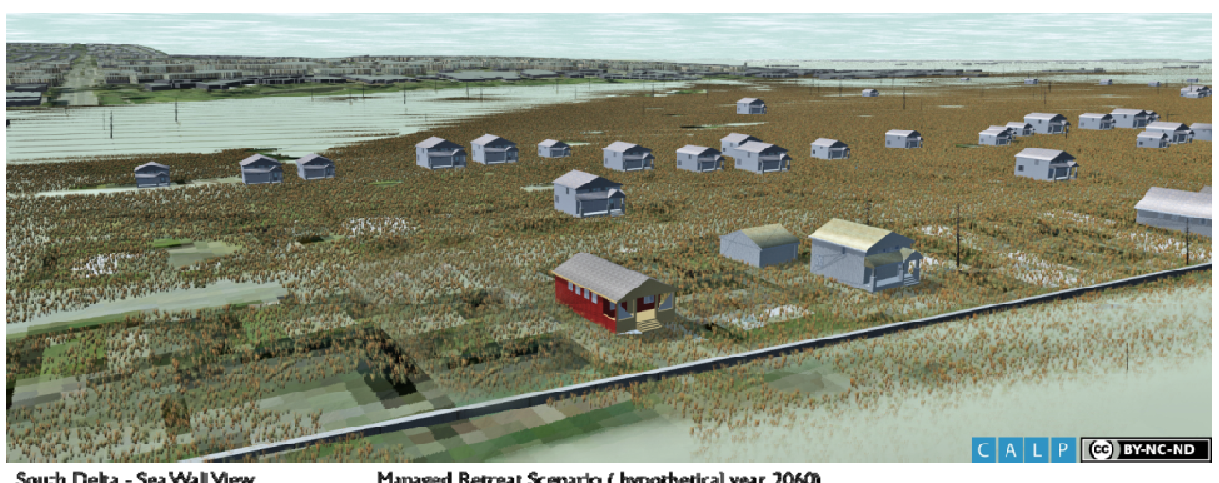


Figure 15. In the final stage of the Managed Retreat Scenario, South Delta is no longer inhabited by residents who have retreated further inland and the area returns to an intertidal zone [37].

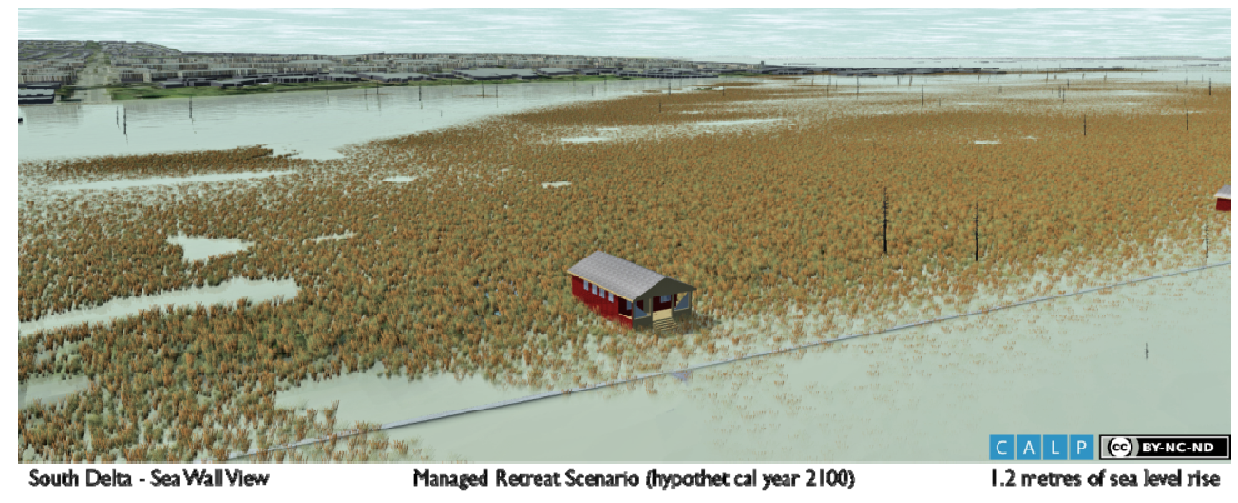

Figure 16. Managed Retreat Scenario, Ladner, Aerial View. The Managed Retreat scenario maintains, strengthens, and raises Delta's dike and seawall infrastructure around Ladner [37].

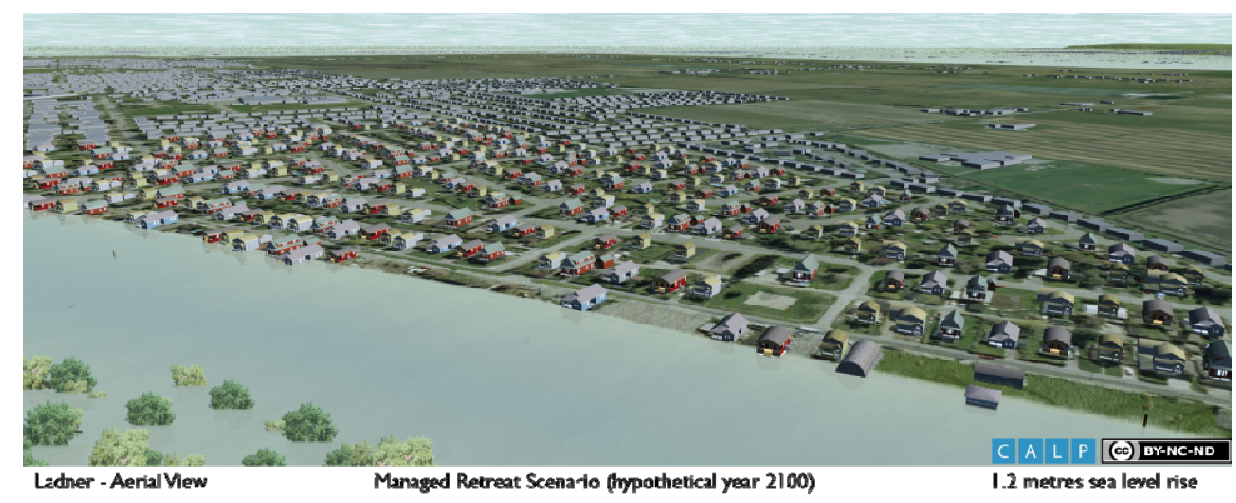

\subsubsection{Build Up}

This "soft" option leaves existing dike and seawall infrastructure largely as is across the Corporation of Delta (see Figure 17). As a result, over time, with rising sea levels, water would more frequently inundate less protected low-lying areas. Current critical infrastructure such as hospitals, schools and fire halls would be raised, new residential development would be built to higher Flood Construction Levels, and older residences would be gradually raised on an individual basis. Major roads would be raised, while minor roads would be left at current elevations. During inundation events, individuals would be responsible for their own properties and access. While it is likely that numerous inundation events would occur by the end of the century, data on the projected frequency of inundation events is, however, not yet available. This scenario, like the others, would likely be developed over many decades. 
Figure 17. In the Build Up Scenario, efforts are focused on raising buildings and critical infrastructure within Delta's low-lying areas so that they are able to accommodate occasional inundation [36].

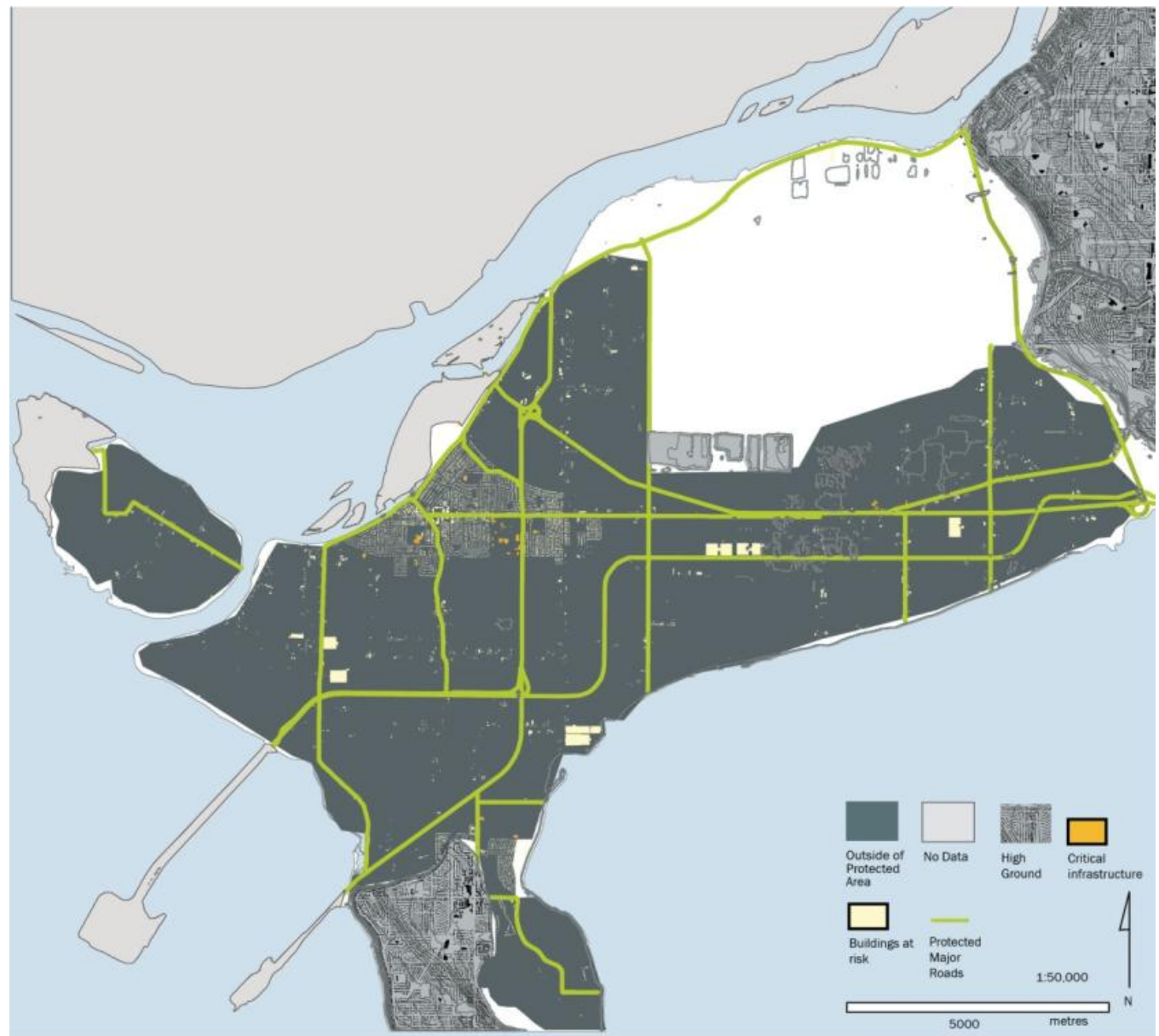

The BC Ministry of Environment recommended a Flood Construction Level, which indicates the recommended elevation of habitable buildings, of $6.2 \mathrm{~m}$ (see Table 3 ).

Table 3. BC provincial Guidelines for Management of Coastal Flood Hazard Land Use [34].

\begin{tabular}{|c|c|c|}
\hline & 2010 Guideline & 2100 Guideline \\
\hline $\begin{array}{l}\text { Guidelines for Management of } \\
\text { Coastal Flood Hazards Land Use }\end{array}$ & (CGD, $\mathrm{m}$ above mean sea level) & (CGD, $\mathrm{m}$ above mean sea level) \\
\hline $\begin{array}{l}\text { Flood Construction Reference } \\
\text { Plane (FCRP) (Designated Flood } \\
\text { Level + estimated wave effect) }\end{array}$ & $3.45 \mathrm{~m}$ & $5.6 \mathrm{~m}$ \\
\hline $\begin{array}{l}\text { Flood Construction Level (Flood } \\
\text { Construction Reference Plane }+ \\
\text { freeboard) }\end{array}$ & $4.05 \mathrm{~m}$ & $6.2 \mathrm{~m}$ \\
\hline
\end{tabular}

The architectural and infrastructure design solutions were all based on local and international precedents, and after viewing the visualizations it became clear that this strategy would require numerous feasibility and engineering studies to properly account for the changes to utilities and drainage systems that would occur under this scenario (see Figures 18 and 19). 
Figure 18. Build Up Scenario, Ladner, Dike View, during periods without inundations [37].

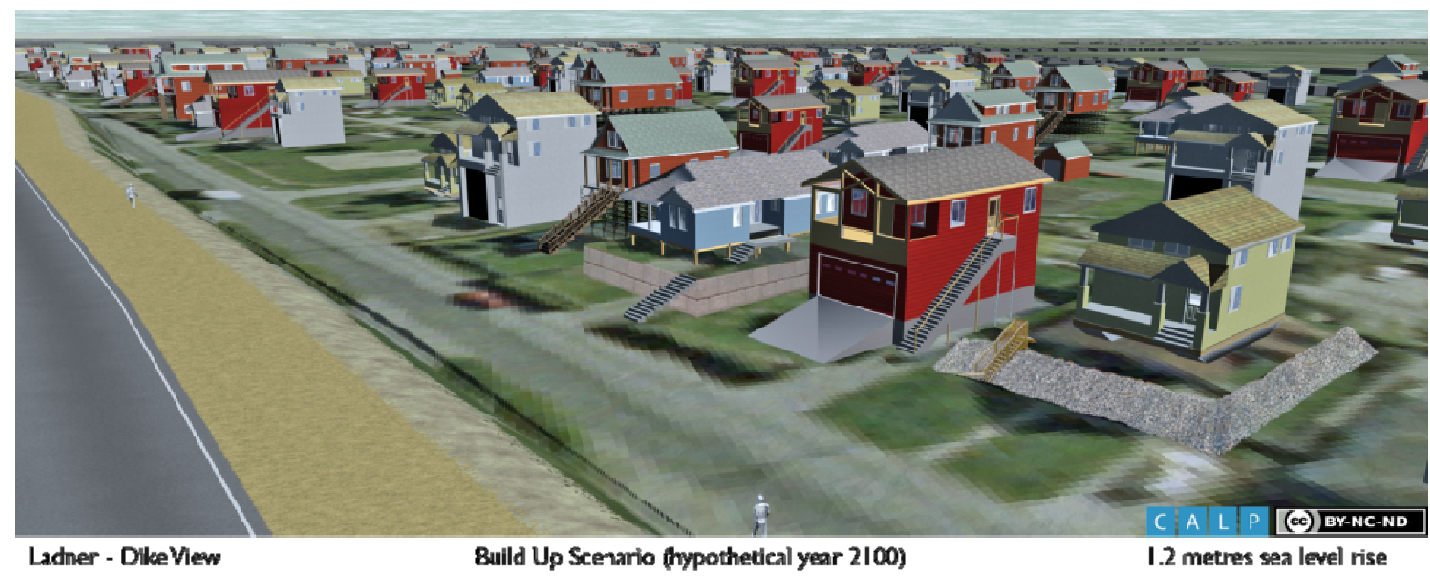

Figure 19. Build Up Scenario, Ladner, Dike View, during periodic inundation [37].

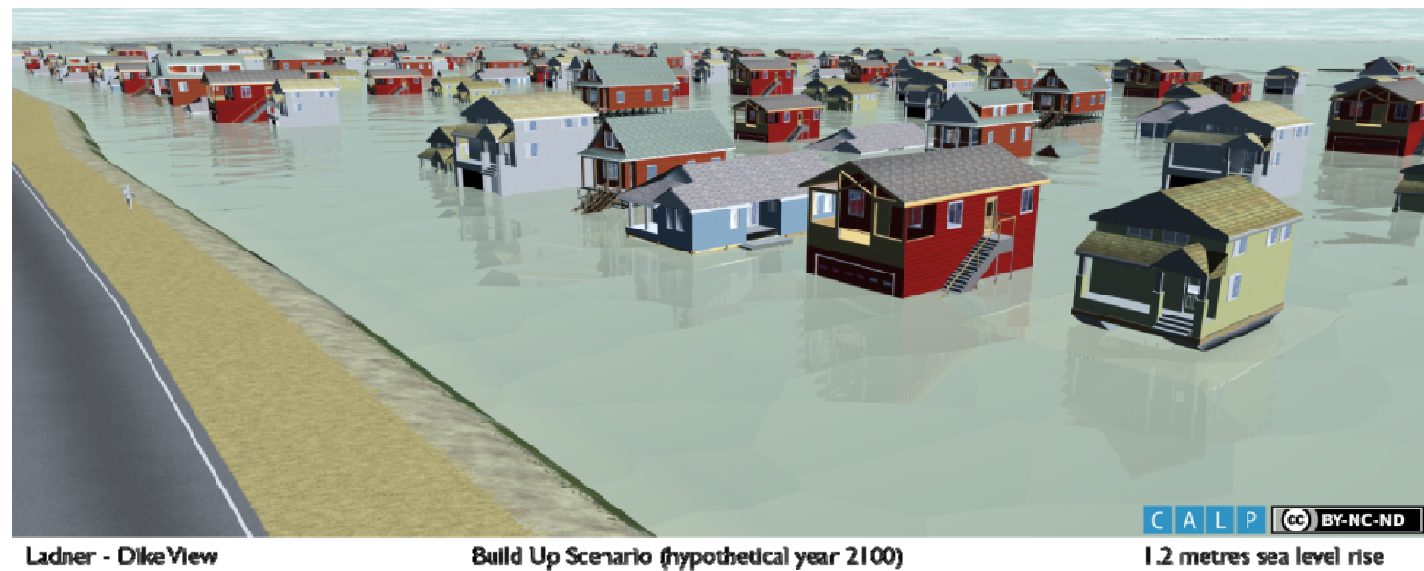

\subsection{Indicator Measurements of the Four Adaptation Scenarios}

For the current condition ("Baseline") and all four future adaptation scenarios ("Hold the Line", "Reinforce and Reclaim", "Managed Retreat" and "Build Up"), the total potentially protected and unprotected areas within the floodplain area (defined as lands at or below $5.6 \mathrm{~m}$ above sea level, GSC) were delineated in GIS. These "footprints" showed how the area of unprotected and protected land changed from the baseline condition, where the footprint is the full sea level rise planning area, as a result of adaptation strategies. Figures 4, 9, 11 and 17 show lands protected (brown) and outside of protected areas (dark grey) areas as a result of adaptation. Areas of higher ground (greater than the Flood Construction Plane Reference Plane; $5.6 \mathrm{~m}$ above sea level), and therefore outside of the sea level rise planning area, were not included in these calculations. Table 4 shows the indicators with descriptions of how they were calculated, along with resulting calculations. Only lands within the sea level rise planning areas are included in the calculations. 
Table 4. Indicator measurements used in a consequence table showing trade-offs among scenarios.

\begin{tabular}{|c|c|c|c|c|c|c|c|}
\hline & Description & Calculation Method & $\begin{array}{c}\text { Baseline } \\
\text { (current condition) }\end{array}$ & $\begin{array}{c}\text { Hold The Line } \\
\text { (future scenario) }\end{array}$ & $\begin{array}{c}\text { Reinforce and Reclaim } \\
\text { (future scenario) }\end{array}$ & $\begin{array}{l}\text { Managed Retreat } \\
\text { (future scenario) }\end{array}$ & $\begin{array}{c}\text { Build Up } \\
\text { (future scenario) }\end{array}$ \\
\hline $\begin{array}{l}\text { Agricultural } \\
\text { land }\end{array}$ & $\begin{array}{l}\text { Total Agricultural land } \\
\text { protected and unprotected }\end{array}$ & $\begin{array}{c}\text { Land within the sea level rise } \\
\text { planning area zoned Agricultural } \\
\text { Land Reserve or with Agriculture } \\
\text { as its primary use }\end{array}$ & $8600 \mathrm{Ha}$ & $\begin{array}{l}\text { Protected: } 7800 \mathrm{Ha} \\
\text { Unprotected: } 800 \mathrm{Ha}\end{array}$ & $\begin{array}{l}\text { Protected: } 7,800 \mathrm{Ha} \\
\text { Unprotected: } 800 \mathrm{Ha}\end{array}$ & $\begin{array}{l}\text { Protected: } 1700 \mathrm{Ha} \\
\text { Unprotected: } 6900 \mathrm{Ha}\end{array}$ & $\begin{array}{c}\text { Protected: } 0 \mathrm{Ha} \\
\text { Unprotected: } 8600 \mathrm{Ha}\end{array}$ \\
\hline $\begin{array}{l}\text { Impacts to } \\
\text { wildlife } \\
\text { habitat }\end{array}$ & Qualitative effect on habitat & $\begin{array}{c}\text { Assessment of relative gain or } \\
\text { loss of habitat based on magnitude } \\
\text { of potentially displaced high } \\
\text { quality habitat [38] }\end{array}$ & $\begin{array}{c}115 \mathrm{~km} \text { of highly } \\
\text { productive intertidal } \\
\text { foreshore habitat } \\
2200 \mathrm{Ha} \text { of riparian } \\
\text { habitat } \\
9500 \mathrm{Ha} \text { of } \\
\text { intertidal habitat } \\
\end{array}$ & $\begin{array}{c}\text { Riparian habitat would } \\
\text { not change significantly, } \\
\text { intertidal habitat would } \\
\text { decrease in extent due to } \\
\text { "coastal squeeze" } \\
\text { outside dikes }\end{array}$ & $\begin{array}{l}\text { Riparian habitat would not } \\
\text { change significantly, intertidal } \\
\text { habitat would decrease less } \\
\text { overall than in Hold The Line } \\
\text { due to generation around } \\
\text { barrier islands }\end{array}$ & $\begin{array}{l}\text { Riparian and } \\
\text { intertidal habitat would } \\
\text { increase in extent }\end{array}$ & $\begin{array}{l}\text { Riparian and intertidal habita } \\
\text { would increase in extent }\end{array}$ \\
\hline Land base & $\begin{array}{l}\text { Total protected (by dike) and } \\
\text { unprotected land }\end{array}$ & $\begin{array}{l}\text { Total protected and } \\
\text { unprotected land in the sea level } \\
\text { rise planning area }\end{array}$ & $\begin{array}{l}\text { Sea level rise planning } \\
\text { area: } 10,200 \mathrm{Ha}, \\
\text { most protected by } \\
\text { current guidelines }\end{array}$ & $\begin{array}{l}\text { Protected: } 9300 \mathrm{Ha} \\
\text { Unprotected: } 900 \mathrm{Ha}\end{array}$ & $\begin{array}{c}\text { Protected: } 9,300 \mathrm{Ha} \\
\text { Unprotected: } 900 \mathrm{Ha} \\
\text { + lands added in barrier islands }\end{array}$ & $\begin{array}{l}\text { Protected: } 2200 \mathrm{Ha} \\
\text { Unprotected: } 8000 \mathrm{Ha}\end{array}$ & $\begin{array}{c}\text { Protected: } 0 \mathrm{Ha} \\
\text { Unprotected: } 10,200 \mathrm{Ha}\end{array}$ \\
\hline $\begin{array}{l}\text { Transportatio } \\
\text { n impacts } \\
\text { (roads) }\end{array}$ & $\begin{array}{l}\text { Total length of roads } \\
\text { protected (raised) and } \\
\text { unprotected } \\
\text { (decommissioned) }\end{array}$ & $\begin{array}{l}\text { Total length of roads raised and } \\
\text { not raised in the sea level rise } \\
\text { planning area }(\mathrm{km})\end{array}$ & $\begin{array}{l}\text { Roads in sea level rise } \\
\text { planning area: } 380 \mathrm{~km}\end{array}$ & $\begin{array}{l}\text { Protected (inside dike): } \\
340 \mathrm{~km} \\
\text { Raised/reinforced: } 0 \mathrm{~km} \\
\text { Decommissioned: } 40 \mathrm{~km}\end{array}$ & $\begin{array}{l}\text { Protected (inside dike): } 340 \mathrm{~km} \\
\text { Raised/reinforced: } 0 \mathrm{~km} \\
\text { Decommissioned: } 40 \mathrm{~km}\end{array}$ & $\begin{array}{c}\text { Protected (inside dike): } \\
110 \mathrm{~km} \\
\text { Raised/reinforced: } 30 \mathrm{~km} \\
\text { Decommissioned: } 240 \mathrm{~km}\end{array}$ & $\begin{array}{l}\text { Raised/reinforced: } 140 \mathrm{~km} \\
\text { Decommissioned: } 240 \mathrm{~km}\end{array}$ \\
\hline $\begin{array}{l}\text { Infrastructure } \\
\text { impacts } \\
\text { (dikes/ } \\
\text { seawalls) }\end{array}$ & $\begin{array}{l}\text { Total length of dikes } \\
\text { protected (raised/reinforced) } \\
\text { and unprotected } \\
\text { (decommissioned) }\end{array}$ & $\begin{array}{l}\text { Total length of dikes raised } \\
\text { (reinforced and maintained) and } \\
\text { decommissioned (not raised or } \\
\text { maintained) in the sea level rise } \\
\text { planning area (km) }\end{array}$ & $\begin{array}{c}\text { Total dike length: } 55 \mathrm{~km} \\
\text { (approximate) }\end{array}$ & $\begin{array}{c}\text { Raised: } 50 \mathrm{~km} \\
\text { Decommissioned: } 5 \mathrm{~km}\end{array}$ & $\begin{array}{c}\text { Raised: } 45 \mathrm{~km}^{1} \\
\text { Decommissioned: } 10 \mathrm{~km}\end{array}$ & $\begin{array}{c}\text { Raised: } 22 \mathrm{~km} \\
\text { Decommissioned: } 33 \mathrm{~km}\end{array}$ & $\begin{array}{c}\text { Raised: } 0 \mathrm{~km} \\
\text { Decommissioned: } 55 \mathrm{~km}\end{array}$ \\
\hline $\begin{array}{l}\text { Infrastructure } \\
\text { impacts } \\
\text { (facilities) }\end{array}$ & $\begin{array}{c}\text { Total number of critical } \\
\text { facilities affected (hospitals, } \\
\text { fire, police, schools) }\end{array}$ & $\begin{array}{c}\text { Total number of hospitals, fire and } \\
\text { police stations, and schools in the } \\
\text { sea level rise planning area }\end{array}$ & $\begin{array}{l}\text { Protected: } 20 \\
\text { Unprotected: } 0\end{array}$ & $\begin{array}{l}\text { Protected: } 20 \\
\text { Unprotected: } 0\end{array}$ & $\begin{array}{l}\text { Protected: } 20 \\
\text { Unprotected: } 0\end{array}$ & $\begin{array}{l}\text { Protected: } 13 \\
\text { Unprotected: } 7\end{array}$ & $\begin{array}{l}\text { Protected: } 20 \text { (if built up) } \\
\text { Unprotected: } 0\end{array}$ \\
\hline $\begin{array}{l}\text { Impact to } \\
\text { buildings }\end{array}$ & $\begin{array}{l}\text { Number of buildings } \\
\text { protected and unprotected }\end{array}$ & $\begin{array}{l}\text { Total number of buildings } \\
\text { protected and unprotected by dike } \\
\text { raising and/or building } \\
\text { modification in the sea level rise } \\
\text { planning area }\end{array}$ & $\begin{array}{l}\text { Protected: } 8663 \\
\text { Unprotected: } 0\end{array}$ & $\begin{array}{c}\text { Protected: } 8511 \\
\text { Unprotected: } 152\end{array}$ & $\begin{array}{l}\text { Protected: } 8511 \\
\text { Unprotected: } 152\end{array}$ & $\begin{array}{c}\text { Protected: } 5688 \\
\text { Unprotected: } 2975 \text { (but not } \\
\text { lost is all relocated to } \\
\text { managed retreat area or } \\
\text { higher ground) }\end{array}$ & $\begin{array}{l}\text { Protected: } 0 \\
\text { Unprotected: } 8663 \text { (but not } \\
\text { lost if all built-up) }\end{array}$ \\
\hline $\begin{array}{l}\text { Public } \\
\text { acceptability }\end{array}$ & Visual impacts & $\begin{array}{l}\text { Assessed by considering the 3D } \\
\text { visualizations of each scenario for } \\
\text { Ladner and/or Beach Grove }\end{array}$ & Not tested & $\begin{array}{c}\text { Extensive view } \\
\text { blockage, significant } \\
\text { landscape change along } \\
\text { dikes and seawalls. } \\
\text { Little change across } \\
\text { interior of sea level rise } \\
\text { planning area. }\end{array}$ & $\begin{array}{l}\text { Considerable view blockage, } \\
\text { significant landscape change } \\
\text { along seawalls, though less } \\
\text { than in Hold The Line. Little } \\
\text { change across interior of sea } \\
\text { level rise planning area. }\end{array}$ & $\begin{array}{l}\text { Major land use and } \\
\text { landscape change } \\
\text { over time; some new dikes } \\
\text { and view blockage } \\
\text { around Ladner. }\end{array}$ & $\begin{array}{l}\text { Widespread } \\
\text { landscape character and land } \\
\text { use changes. }\end{array}$ \\
\hline
\end{tabular}

${ }^{1}$ Does not include barrier islands, which decreases the length or height of sea dikes to be raised. 
Table 4. Cont

\begin{tabular}{|c|c|c|c|c|c|c|c|}
\hline & Description & Calculation Method & $\begin{array}{c}\text { Baseline } \\
\text { (current condition) } \\
\end{array}$ & $\begin{array}{c}\text { Hold The Line } \\
\text { (future scenario) }\end{array}$ & $\begin{array}{c}\text { Reinforce and Reclaim } \\
\text { (future scenario) }\end{array}$ & $\begin{array}{l}\text { Managed Retreat } \\
\text { (future scenario) }\end{array}$ & $\begin{array}{c}\text { Build Up } \\
\text { (future scenario) }\end{array}$ \\
\hline $\begin{array}{l}\text { Public } \\
\text { acceptability }\end{array}$ & $\begin{array}{c}\text { Acceptability to concerns } \\
\text { identified by stakeholder } \\
\text { working group }\end{array}$ & $\begin{array}{l}\text { Identified by considering the } \\
\text { maps, 3D visualizations and full } \\
\text { visioning package for each } \\
\text { scenario for Ladner and/or } \\
\text { Boundary Bay }\end{array}$ & Not Tested & $\begin{array}{l}\text { Less suited for } \\
\text { Boundary Bay due to } \\
\text { challenges of blocking } \\
\text { views, more suited for } \\
\text { Ladner due to } \\
\text { return-on-investment. }\end{array}$ & $\begin{array}{l}\text { Best suited for Boundary Bay } \\
\text { due to reduced view blockage, } \\
\text { suitability for habitat } \\
\text { restoration, appropriate for } \\
\text { storms across Boundary Bay; } \\
\text { less suited for Ladner due to } \\
\text { spatial/Fraser River constraints } \\
\text { and Westham Island may serve } \\
\text { as a kind of barrier already. } \\
\text { Generally this was a more } \\
\text { acceptable alternative to Hold } \\
\text { The Line. }\end{array}$ & $\begin{array}{l}\text { May be suitable to protect } \\
\text { most valuable lands/areas } \\
\text { of concentrated } \\
\text { infrastructure and people } \\
\text { due to logistics and return- } \\
\text { on-investment. Larger role } \\
\text { of government than in } \\
\text { Build Up. }\end{array}$ & $\begin{array}{l}\text { May be suitable for certain } \\
\text { areas where there aren't } \\
\text { resources available for dike } \\
\text { raising, sparse population and } \\
\text { infrastructure that wouldn't } \\
\text { warrant widespread diking. } \\
\text { Changes to property access } \\
\text { within built-up areas though } \\
\text { building function could be } \\
\text { maintained. Larger role for } \\
\text { private land owner than in } \\
\text { Managed Retreat. }\end{array}$ \\
\hline $\begin{array}{l}\text { Policy change } \\
\text { required }\end{array}$ & $\begin{array}{c}\text { Degree to which } \\
\text { current policies would need to } \\
\text { be changed }\end{array}$ & $\begin{array}{l}\text { Based on outcomes of } \\
\text { policy workshop with Delta } \\
\text { planning staff }\end{array}$ & N/A & $\begin{array}{l}\text { Most in accordance with } \\
\text { current policy }\end{array}$ & $\begin{array}{l}\text { In accordance with current } \\
\text { policy, though extensive } \\
\text { barrier islands new for Delta }\end{array}$ & $\begin{array}{l}\text { Retreat is least in } \\
\text { accordance with } \\
\text { current policy }\end{array}$ & $\begin{array}{l}\text { Use of Flood Construction } \\
\text { Levels in accordance with } \\
\text { current policy }\end{array}$ \\
\hline $\begin{array}{l}\text { Culture/herita } \\
\text { ge impacts }\end{array}$ & $\begin{array}{l}\text { Number of cultural/heritage } \\
\text { sites protected by } \\
\text { adaptive action }\end{array}$ & $\begin{array}{l}\text { Total number of culturally and } \\
\text { historically important features in } \\
\text { sea level rise planning area that } \\
\text { would be protected from } \\
\text { inundation after adaptation } \\
\text { strategies implemented }^{2}\end{array}$ & 12 & 11 & 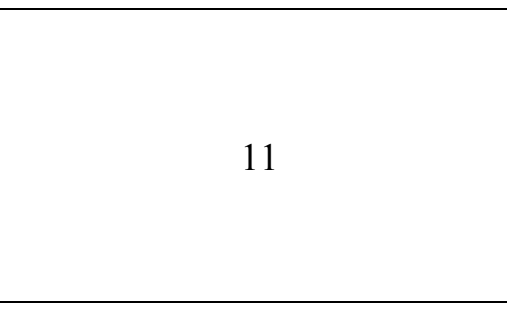 & $x^{2}=1$ & 12 (if all built up) \\
\hline Costs & $\begin{array}{l}\text { Capital/implementation } \\
\text { costs }^{3}\end{array}$ & $\begin{array}{l}\text { Total length of roads and/or dikes } \\
\text { raised/reinforced multiplied by a } \\
\text { cost of } \$ 1.13 \text { million/km [39] }\end{array}$ & $\begin{array}{l}380 \mathrm{~km} \text { of roads } \\
55 \mathrm{~km} \text { of dikes }\end{array}$ & $\begin{array}{l}\$ 0 \text { for raised roads } \\
\$ 51 \text { million for } \\
\text { raised dikes }\end{array}$ & $\begin{array}{l}\$ 0 \text { for raised roads } \\
\$ 51 \text { million for raised dikes }+ \\
\text { cost of barrier islands }\end{array}$ & $\begin{array}{l}\text { \$34 million for raised } \\
\text { roads } \\
\$ 25 \text { million for raised } \\
\text { dikes }\end{array}$ & $\begin{array}{l}\$ 159 \text { million for raised roads } \\
\$ 0 \text { for raised dikes }\end{array}$ \\
\hline Damages & $\begin{array}{l}\text { Damage to private/public } \\
\text { property from } \\
\text { inundation event }\end{array}$ & $\begin{array}{c}\text { Protected/Unprotected area } \\
\text { (Figures } 8 \text {-11) } \times \text { Property } \\
\text { value }[40] \text { for land within the sea } \\
\text { level rise planning area }\end{array}$ & $\$ 5.85$ billion & $\begin{array}{l}\$ 5.8 \text { billion protected } \\
\$ 49 \text { million converted }\end{array}$ & $\begin{array}{l}\$ 5.8 \text { billion protected } \\
\$ 49 \text { million converted }\end{array}$ & $\begin{array}{l}\$ 4.0 \text { billion protected } \\
\$ 1.9 \text { billion converted }\end{array}$ & $\begin{array}{c}\$ 3.8 \text { billion in land } \\
\text { sometimes inundated } \\
\$ 1.6 \text { billion in buildings } \\
\text { "protected" if raised } \\
\$ 408.5 \text { million in buildings }\end{array}$ \\
\hline
\end{tabular}

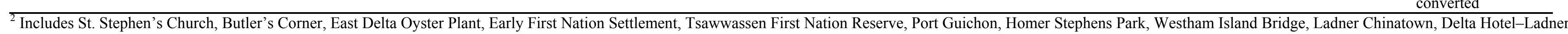
Landing, W.H Ladner House Site, Kirkland House.

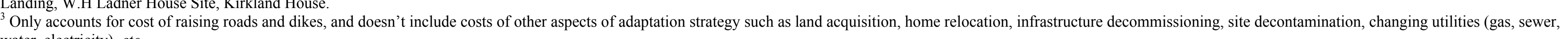
${ }^{4}$ water, electricity), etc.

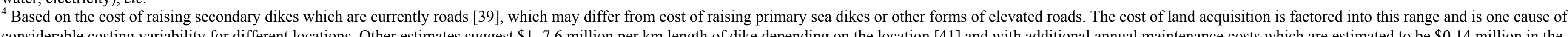

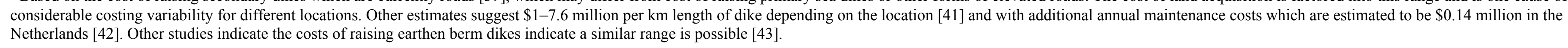




\section{Discussion and Conclusions}

The research team has developed a working relationship with the community of Delta that began in 2006, and continues today with a recent policy development workshop with staff planners as well as a presentation of this work to the mayor and local council. The results of the scenario development, mapping and visualization imagery, and assessment of indicators provide the community and decision-makers with a structured set of options and holistic listing of relative impacts and implications. For example, the 'hold the line' scenario protects most of the farmland (7800 ha), but requires the longest length of dike reconstruction (about $50 \mathrm{~km}$ ); the 'managed retreat' scenario protects only 1700 ha, but requires only 22 kilometers of raised diking. There is no attempt here to pick a 'preferred alternative'; rather, the intent is to foster an informed community-wide discussion about the topic that challenges people to take the issue seriously, consider a range of options, and come up with variations or combinations of these scenarios, or new scenarios altogether. Issues of this complexity and social sensitivity, given possible threats to livelihoods, resources, land values, community character and lifestyles, cannot be addressed simplistically. The hope is that illustrating both conceptual adaptation options and an accessible and engaging planning process that can be widened and continued, provides a defensible space for the Corporation of Delta to be proactive, bringing citizens and stakeholders into a realistic and constructive dialogue on a crucial matter. A major success of this methodology is the ability for the visioning packages to engage in more meaningful conversations about specific adaptation strategies, their implications, phasing, implementation, acceptability, and how they may be refined into coherent policy pathways.

Time will tell whether this community-based research and visioning approach stimulates polarized dissent, disappears from view, or fosters rational and sensitive planning involving all stakeholders. Initial responses from participating stakeholders, staff, and council-members suggests that the process and products have been useful, and are worthy of being shared more widely with the community. New and previously radical terms and concepts in Delta, such as Managed Retreat and barrier islands, are now in the public domain and on people's lips. "Win-win" situations became clear, such as the potential for the Reinforce and Reclaim strategy to make up for lost habitat resulting from the "coastal squeeze" of sea level rise, while at the same time reducing the extent of seawall raising. The visual package of realistic visualization combined with quantified mapping and assessment data, provides planners and communications staff with powerful tools to attract attention and advance learning. For example, one staff member began to reflect on the Build Up strategy in that it would likely lead to land owners teaming up to form higher-density clusters/adaptation stratas/build-up islands which would share the cost of building up; an implicit incentive to increase density. In all cases, more meaningful conversations on the cost-structures of each strategy (e.g., private or public responsibility), and potential revenue generation (e.g., recreational opportunities with Reinforce and Reclaim) emerged from workshops with the public and practitioners. Based on the study findings and feedback from the working group and staff, we provide below some recommendations for Delta that would also be applicable to many communities engaging in adaptation planning. 


\subsection{Overarching Recommendations for Advancing Adaptation}

Communities such as Delta facing critical threats due to climate change should continue to expand and deepen the dual strategy for successful adaptation planning described above. Further initiatives on social learning and capacity-building should embrace existing and new public engagement/educational opportunities, including methods such as those employed in this study and a media strategy to take advantage of media interest and responsible information dissemination. The goal is for an inclusive, structured, and informed public dialogue with shared learning on all sides, conducted well before major decisions are taken. As the research team has been working in Delta for at least 6 years, made up of several 2-4 year projects, much of the receptiveness and willingness that both staff and the public had to this work is the result of this longer-term commitment and trust built up between stakeholders. We conclude that any successful adaptation planning process would benefit from being similarly longer-term. Conversations with other international professionals in this field suggest that 10 years is the minimum duration to bring an adaptation project from initiation to implementation [44]. Building public support for policy change and implementation of adaptation measures will be important in attracting funding and reducing uncertainties and costs.

One of the major challenges encountered throughout the project was the incorporation of varying forms and sources of data. For example, the inundation modeling available to Delta came from several different consultants, used different hydrological models, and inconsistent dike breach locations and sea level rise assumptions. It was necessary to agglomerate and generalize the data in order to form coherent, measurable scenarios. Other findings on the successes and challenges of implementing a climate change visioning exercise have been recently published by the research team $[4,6,7,26]$.

In parallel, further work on technical analysis and strategic planning to support decision-making is essential in order to:

- Provide a strong basis for lobbying higher government and other potential funding sources;

- Identify and exploit win/win opportunities in meeting multiple objectives such as safeguarding community assets such as wildlife and agricultural production, meeting adopted carbon emission reduction targets and reducing dependency on fossil fuels, providing more jobs in the community and developing the local tax base, improved transit, etc.;

- Form strategic alliances with other communities and agencies on issues such as local food security and funding technical studies, to provide continuity and mutual support in infrastructure approaches across municipal boundaries, for example.

\subsection{Specific Recommendations for Communities Like Delta}

In accordance with this dual strategy, Delta should consider the following steps as a possible road-map toward decision-making and action on sea level rise. Since most Canadian and many international communities share similar regulatory processes, and since many of these recommendations are general in nature, these recommendations are applicable to a broad range of communities engaging in climate change adaptation planning. 
4.2.1. Plan for Amending the OCP to Systematically Incorporate Sea Level Rise and Related Climate Change Issues

The current Official Community Plan has no reference to sea level rise. The next update should give more emphasis to these issues to ensure that future planning is resilient to future conditions. This provides an approximately 5 year window in which to establish the community capacity building program and planning studies. It also takes advantage of the period after the recent elections to initiate serious conversations on future critical issues.

4.2.2. Incorporate Sea Level Rise Planning into the Ongoing Activities and Operations of the Corporation

This should apply across departments, wherever relevant, in order to avoid unforeseen legacies and costly inefficiencies through not thinking ahead. Opportunities to advance dialogue and adaptive planning through ongoing activities such as Local Area Plans, park plans, and community outreach programs should be seized in coordination with the larger strategy.

\subsubsection{Adopt Amended Sea Level Rise Planning Area Terminology}

The BC Ministry of Environment has recently proposed the creation of Sea Level Rise Planning Areas. For Delta, we recommend that this area be delineated as all lands below $5.6 \mathrm{~m}$ (based on the Flood Construction Reference Plane, Table 3). If there were to be a dike breach, lands within the Sea Level Rise Planning area could be inundated, although it is unlikely that the entire area would flood at the same time. The designation would trigger adaptive planning to sea level rise impacts within the vulnerable areas.

\subsubsection{Link this Project to Delta's ICLEI Adaptation Process}

The Corporation of Delta is currently working through the ICLEI process for municipal climate change adaptation. Sea level rise is probably the most far-reaching and iconic of the many impacts of climate change that will affect Delta. Outcomes and implications of this project should be integrated into the ICLEI process, in order to address important interactions with other climate change vulnerabilities, impacts, and adaptation/mitigation strategies.

\subsubsection{Develop Collaborations and Alliances}

Adapting to sea level rise requires collaboration with neighboring communities and many levels of government as stakeholders, funders, providers of additional staff and data resources, reviewers, etc. An initial list of key partners likely to have an interest in sea level rise adaptation in Delta would include First Nation communities, realty and land-owner organizations, adjoining cities and regional government, utilities and ports, provincial ministries and Federal departments, and environmental/social organizations. 


\subsubsection{Develop and Initiate a Comprehensive Community Engagement Plan}

The residents of Delta should be engaged as soon as possible to begin the long process of discussing and planning for their community's future, in parallel with the necessary technical studies (suggested below). Though the actual implementation of planning choices may take place over decades, it is important for residents and stakeholders to feel heard and to share ownership of Delta's emerging approach to climate change adaptation.

We have found that the local working group, representing all major stakeholders, is an effective way to gain early input and bridge to various community groups. Building on both the scenario visioning methods used in this study and the ICLEI program, a 2-3 year process should be conducted to build awareness and capacity. An early community survey would be very helpful in assessing the current state of knowledge and opinion, with a later survey to gauge progress in achieving increased preparedness and understanding of adaptation needs. Multiple community sectors and communication channels (e.g., schools, websites, media outlets) will be necessary in order to reach people in their own cultural and geographic groups. Residents and stakeholders across Delta should be consulted, not just those located in the Sea Level Rise Planning Area, since there may be knock-on effects. Experts in various related topics could be brought in to inform discussions. Use of credible science-based visual media such as adaptation mapping, iconic visualizations, and images from built precedents elsewhere, should be used to gain attention, improve understanding, and help convince senior government and funding sources.

Existing and new or modified scenarios should be discussed and documented in the context of other community priorities. This 2-3 year process to build an informed community and gather the most promising ideas on adaptation could then lead into a formal planning and consultation process for the OCP.

\subsubsection{Begin Detailed Analysis}

This project raised many important questions and issues that will need to be addressed through additional detailed study before the community can move forward with formal planning and decision-making. Some of these studies may be conducted through modifying ongoing budgeted processes, or could be shared with other partners. Delta should consider how to stagger these studies over the next 2-5 years. Needed studies include:

i. A "No Action" Scenario developed in detail, taking into account a full range of impacts such as frequency of flooding projections, storm surge events, Fraser River flooding and increased rainfall intensity. This will also give a better understanding of damage costs and implications potentially avoided by the scenarios.

ii. Costing Studies: comprehensive assessments of the land, property, and ecological stock at risk and its value for the Delta community. Furthermore a costing study of the various adaptation options would be influential on decision-making. The absence of these kinds of analysis as part of this study is a limitation.

iii. Insurance and Disaster Relief Study, consulting with private insurance companies and all levels of government to get a better understanding of private and public flood insurance issues. 
iv. Soil and Saltwater Intrusion Study, addressing agricultural soil quality and elevations in the Sea Level Rise planning area to get a better understanding of which agricultural parcels are most valuable in terms of soil quality, and which are less vulnerable to salinization of the water table. A study should be conducted to model and project potential saltwater intrusion of the groundwater table as sea levels rise.

v. Habitat Study: a detailed study of habitat within the Sea Level Rise Planning Area and areas outside the dikes, to assess which parcels are most valuable, which are at risk to coastal squeeze, which could support habitat restoration, etc.

vi. Feasibility Study for Key Adaptation Measures, considering costs, phasing, etc., in the context of future cost increases in energy and other key variables

vii. Unfunded liabilities study of existing municipal infrastructure to determine how many years existing systems will last, how much is anticipated in on-going maintenance costs, and how much tax base is necessary to support these expenditures.

\subsubsection{Conduct an Area by Area Vulnerability Analysis and Aggregate for Overall Planning}

Beyond the two case study areas modeled in this project, there are more case study areas with unique dike and other conditions that also need to be studied, such as Annacis Island and Westham Island. Risk assessments for flood control infrastructure and vulnerability, as well as adaptation opportunities, should be completed for all areas in the near future.

Such a program is obviously expensive and daunting to any community, yet these are the sort of measures that many vulnerable communities around the world will need to fund and undertake if they are to survive intact in the long term. Opportunities for synergies with other community programs and partners will become crucial to meeting adaptation, mitigation and other objectives. The methods described in this paper are not a panacea for addressing all these hugely challenging issues, but it is argued that they can help move the agenda forward and perhaps overcome some hurdles of apathy, lack of agency, and social engagement in finding local solutions. While climate change poses significant risks and challenges to communities like Delta, there are many potential solutions to be debated and developed over time. It is hoped that adoption of best practices such as the visioning methods described here, can foster further dialogue, policy development, and action in adapting to climate change.

\section{Acknowledgments}

This project has involved many people generously sharing their time and expertise over many years: The Corporation of Delta for their support. Key staff include Hugh Fraser, Mike Brotherston, Angela Danyluk, Thomas Leatham, Marcy Sangret, and Lisa King. The Working Group on this project included Firth Bateman, Tom Bears, Stuart Bowyer, Robert Butler, Erica Crawford-Boettcher, Darrell Desjardin, Angelika Hedley, Carla Marshall, Chris Reid, Todd Sinclair, Robert Tremblay, and Paul van Westendorp. Jeff Carmichael provided modeling support, scenario development, and local government expertise. Civil Servants with the Province of British Columbia include Neil Peters, Inspector of Dikes, Jesal Shah at the Ministry of Environment and Tina Neale and Jenny Fraser at the Climate Action Secretariat. Invaluable technical guidance came from John Readshaw (SNC-Lavalin), 
Thomas Reeve (Delcan), and Stewart Cohen (Environment Canada). Funding support was provided by Natural Resources Canada, through the Regional Adaptation Collaborative program. We thank Jim Vanderwal and the staff at the Fraser Basin Council for administering this collaboration. This project was also funded by GEOmatics for Informed DEcisions (GEOIDE), a Networks of Centres of Excellence program (NCE) by the Government of Canada. Final thanks to Adelle Airey, office manager at UBC CALP.

\section{Conflict of Interest}

The authors declare no conflict of interest.

\section{References}

1. Smit, B.; Burton, I.; Klein, R.; Wandel, J. An anatomy of adaptation to climate change and variability. Climatic Change 2000, 45, 223-251.

2. Birkmann, J.; Garschagen, M.; Kraas, F.; Quang, N. Adaptive urban governance: New challenges for the second generation of urban adaptation strategies to climate change. Sustain. Sci. 2010, 5 , 185-206.

3. Hunt, A.; Watkiss, P. Climate change impacts and adaptation in cities: A review of the literature. Climatic Change 2010, 104, 13-49.

4. Shaw, A.; Sheppard, S.R.J.; Burch, S.; Flanders, D.; Weik, A.; Carmichael, J.; Robinson, J.; Cohen, S. How futures matter-Synthesizing, downscaling, and visualizing climate change scenarios for participatory capacity building. Global Environ. Change 2009, 19, 447-463.

5. Tatebe, K.; Shaw, A.; Sheppard, S.R.J. Technical Report on Local Climate Change Visioning for Delta: Findings and Recommendations; Version 1.0, 22 February 2010; Collaborative for Advanced Landscape Planning, University of British Columbia: Vancouver, BC, USA, 2010; p. 42.

6. Sheppard, S.R.J.; Shaw, A.; Flanders, D.; Burch, S.; Weik, A.; Carmichael, J.; Robinson, J.; Cohen, S.J. Future visioning of local climate change: A framework for community engagement and planning with scenarios and visualization. Futures 2011, 43, 400-412.

7. Burch, S.; Sheppard, S.R.J.; Shaw, A.; Flanders, D. Planning for climate change in a flood-prone community: Municipal barriers to policy action and the use of visualizations as decision-support tools. J. Flood Risk Manag. 2010, 3, 126-139.

8. Flanders, D. NASA World Wind. Available online: http://worldwind.arc.nasa.gov (accessed on 31 August, 2012)

9. Picketts, I.M.; Werner, A.T.; Murdock, T.Q.; Curry, J.; Dery, S.J.; Dyer, D. Planning for climate change adaptation: Lessons learned from a community-based workshop. Environ. Sci. Policy 2012, 17, 82-93.

10. Cohen, S.J.; Waddell, M.W. Climate Change in the 21st Century; McGill-Queen's University Press: Montreal, QC, Canada, 2009.

11. Liepa, I. Adapting to Climate Change in Kimberley; BC Report and Recommendations; Columbia Basin Trust: Castlegar, BC, Canada, 2009. 
12. Schneider, S.H.; Semenov, S.; Patwardhan, A.; Burton, I.; Magadza, C.H.D.; Oppenheimer, M.; Pittock, A.B.; Rahman, A.; Smith, J.B.; Suarez, A.; et al. Assessing Key Vulnerabilities and the Risk from Climate Change. In Climate Change 2007: Impacts, Adaptation and Vulnerability. Contribution of Working Group II to the Fourth Assessment Report of the Intergovernmental Panel on Climate Change; Parry, M.L., Canziani, O.F., Palutikof, J.P., van der Linden, P.J., Hanson, C.E., Eds.; Cambridge University Press: Cambridge, UK, 2007; pp. 779-810.

13. Adger, W.N.; Dessai, S.; Goulden, M.; Hulme, M.; Lorenzoni, I.; Nelson, D.R.; Naess, L.O.; Wolf, J.; Wreford, A. Are there social limits to adaptation to climate change? Climatic Change 2009, 93, 335-354.

14. Adger, W.N.; Arnell, N.W.; Tompkins, E.L. Successful adaptation to climate change across scales. Global Environ. Change 2005, 15, 77-86.

15. Burton, I.; Malone, E.; Huq, S. United Nations Development Programme 2005 Adaptation Policy Frameworks for Climate Change: Developing Strategies Policies and Measures; Technical Papers 1-8. United Nation Development Programme; Lim, B., Spanger-Siegfried, E., Eds.; Cambridge University Press: Cambridge, UK. 2004.

16. Dessai, S.; Lu, X.; Risbey, J.S. On the role of climate scenarios for adaptation planning. Global Environ. Change 2005, 15, 87-97.

17. International Council for Local Environmental Initiatives (ICLEI) Canada. Changing Climate, Changing Communities. In Guide and Workbook for Canadian Municipalities; ICLEI Canada: Toronto, ON, Canada, 2010.

18. King County. King County Climate Action Plan; King County: Seattle, WA, USA, February 2009.

19. Ligeti, E.; Penney, J.; Wieditz, I. Cities preparing for climate change. A study of six urban regions. Clean Air Partnership: Toronto, May 2007. Available online: http://www.cleanair partnership.org (accessed on 12 January 2012).

20. King County. King County Strategic Climate Action Plan; King County, Seattle, WA, USA, June 2012.

21. Columbia Basin Trust. Adaptation Resource Kit-Six-Step Planning Process. 2010. Available online: http://adaptationresourcekit.squarespace.com/six-step-planningprocess/ (accessed on 9 December 2011).

22. Pond, E.; Schroth, O.; Sheppard, S.R.J.; Muir-Owen, S.; Liepa, I.; Campbell, C.; Flanders, D.; Tatebe, K. Local Climate Change Visioning and Landscape Visualizations: Guidance Manual. Collaborative for Advanced Landscape Planning; University of British Columbia: Vancouver, BC, Canada, 2010.

23. Rapaport, E. Musquodoboit Harbour: Assessing Rural Vulnerability. Environmental Planning Studio Prepared for the School of Planning; Dalhousie University: Halifax, NS, Canada, 2011.

24. NRCan Sea Level Rise Adaptation Planning Study for Halifax Harbour. Committee of the Whole, Halifax Regional Council, 9 February 2010. Available online: http://halifax.ca/regionalplanning/documents/SLRCowFeb92010revisedforwebsite.pdf (accessed on 31 May 2012). 
25. Cohen, S.J.; Sheppard, S.R.J.; Shaw, A.; Flanders, D.; Burch, S.; Taylor, B.; Hutchinson, D.; Cannon, A.; Hamilton, S.; Burton, B.; et al. Remembering the snows of yesteryear-Public responses to local climate change visioning of mountain snow packs and future community development in the District of North Vancouver, British Columbia, Canada. Mitig. Adapt. Strateg. Glob. Chang. 2012, 17, 25-49.

26. Schroth, O.; Pond, E.; Muir-Owen, S.; Campbell, C.; Sheppard, S.R.J. Tools for the Understanding of Spatio-Temporal Climate Scenarios in Local Planning: Kimberley, BC, Case Study; Swiss National Science Foudation SNSF: Bern, Switzerland, 2009. Available online: http://www.lviz.org/?p=231 (accessed on 31 May 2012).

27. Sheppard, S.R.J. Visualizing Climate Change: A Guide to Visual Communication of Climate Change and Developing Local Solutions; Earthscan/Routledge: Abingdon, UK, 2012.

28. Pond, E. UBC-CALP. Available online: http://www.calp.forestry.ubc.ca/wp-content/uploads/ 2010/02/CALP-Visioning-Guidance-Manual-Version-1.1.pdf (accessed on 31 August 2012).

29. Barron, S.; Flanders, D.; Pond, E.; Tatebe, K.; Canete, G.; Sheppard, S.R.J.; Carmichael, J.; Muir-Owen, S. Delta-RAC Sea Level Rise Adaptation Visioning Study Policy Report; University of British Columbia: Vancouver, Canada, 2012.

30. Flanders, D.; Barron, S.; Pond, E.; Canete, G.; Tatebe, K.; Carmichael, J.; Cohen, S.J.; Muir-Owen, S.; Sheppard, S.R.J. Delta-RAC Sea Level Rise Adaptation Visioning Study Technical Report; University of British Columbia: Vancouver, Canada, 2012.

31. Delta RAC Sea Level Rise Adaptation. Available online: http://www.delta-adaptation-bc.ca (accessed on 31 August, 2012).

32. Delcan-DHV. 2011. Sea Level Rise Breach Analysis-Technical Memorandum; Corporation of Delta: Delta, BC, Canada, 2011.

33. BC Ministry of Environment. Climate Change Adaption Guidelines for Sea Dikes and Coastal Flood Hazard Land Use-Sea Dike Guidelines; Ausenco Sandwell: Brisbane, Australia, 2011.

34. BC Ministry of Environment. Climate Change Adaption Guidelines for Sea Dikes and Coastal Flood Hazard Land Use-Guidelines for Management of Coastal Flood Hazard Land Use; Ausenco Sandwell: Brisbane, Australia, 2011.

35. UBC-CALP. Personal communication.

36. Canete, G. UBC-CALP. Personal communication.

37. Flanders, D. UBC-CALP. Personal communication.

38. Fraser Estuary Management Program (FREMP). Available online: http://www.bieapfremp.org/ main_fremp.html (accessed on 31 May 2012).

39. Kerr Wood Leidel. 2007. Flood Management Study_Draft Final Report; Corporation of Delta: Delta, BC, Canada.

40. BC Assessment. Available online: http://www.bcassessment.ca (accessed on 31 August 2012).

41. Linham, M.M.; Nicholls, R.J. Technologies for Climate Change Adaptation. Coastal Erosion and Flooding; TNA Guidebook Series, UNEP: Nairobi, Kenya, 2010.

42. Associated Programme on Flood Management (APFM, Adviescommissie Primaire Waterkeringen). 2006. Tussensprint naar 2015-advies over de financiering van primaire waterkeringen voor de bescherming van Nederland tegen overstromingen (in Dutch). Available online: http://climatetechwiki.org/content/sea-dikes (accessed on 31 May 2012). 
43. Lake Okeechobee and the Herbert Hoover Dike, U.S. Army Core of Engineers. Available online: http://www.saj.usace.army.mil/Divisions/ProgramProjectMgt/Branches/EcoSys/Okeechobee/Lak eO/DOCS/LakeOandHHDike.pdf (accessed on 31 August 2012).

44. Communication with speaker from the Consulate General of The Netherlands at Flood Management and Mitigation Seminar, hosted by Delcan Engineers and Emergency Management BC, May 2012. Available online: http://www.youtube.com/watch? $v=q I q l v p w l P L k \& f e a t u r e=$ player_embedded (accessed on 31 May 2012).

(C) 2012 by the authors; licensee MDPI, Basel, Switzerland. This article is an open access article distributed under the terms and conditions of the Creative Commons Attribution license (http://creativecommons.org/licenses/by/3.0/). 